\title{
Exogenous hydrogen sulfide restores cardioprotection of ischemic post-conditioning via inhibition of mPTP opening in the aging cardiomyocytes
}

\author{
Hongzhu Li ${ }^{1,3^{*}}$, Chao Zhang ${ }^{2}$, Weiming Sun ${ }^{1}$, Lina Li ${ }^{1}$, Bo Wu${ }^{1}$, Shuzhi Bai ${ }^{1}$, Hongxia Li ${ }^{1}$, Xin Zhong ${ }^{1,3}$, \\ Rui Wang ${ }^{4}$, Lingyun $\mathrm{Wu}^{5}$ and Changqing $\mathrm{Xu}^{1,3^{*}}$
}

\begin{abstract}
The physiological and pathological roles of hydrogen sulfide $\left(\mathrm{H}_{2} \mathrm{~S}\right)$ in the regulation of cardiovascular functions have been recognized. $\mathrm{H}_{2} \mathrm{~S}$ protects against the hypoxia/reoxygenation $(\mathrm{H} / \mathrm{R})$-induced injury and apoptosis of cardiomyocytes, and ischemic post-conditioning (PC) plays an important role in cardioprotection from H/R injury in neonatal cardiomyocytes but not in aging cardiomyocytes. Whether $\mathrm{H}_{2} \mathrm{~S}$ is involved in the recovery of $\mathrm{PC}$-induced cardioprotection in aging cardiomyocytes is unclear. In the present study, we found that both $\mathrm{H} / \mathrm{R}$ and $\mathrm{PC}$ decreased cystathionine- $\gamma$-lyase (CSE) expression and the production rate of $\mathrm{H}_{2} \mathrm{~S}$. Supplementation of NaHS protected against $\mathrm{H} / \mathrm{R}$-induced apoptosis, the expression of cleaved caspase-3 and cleaved caspase-9, the release of cytochrome $c$ (Cyt c), and mPTP opening. The addition of NaHS also counteracted the reduction of cell viability caused by $\mathrm{H} / \mathrm{R}$ and increased the phosphorylation of ERK1/2, PI3K, Akt, GSK-3 $\beta$ and mitochondrial membrane potential. Additionally, NaHS increased $\mathrm{BCl}-2$ expression, promoted PKC- $\varepsilon$ translocation to the cell membrane, and activated mitochondrial

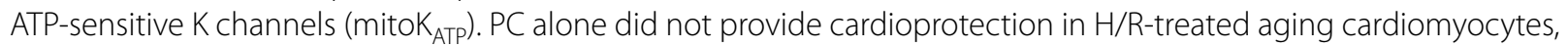
which was significantly restored by the supplementation of $\mathrm{NaHS}$. In conclusion, our results suggest that exogenous $\mathrm{H}_{2} \mathrm{~S}$ restores $\mathrm{PC}$-induced cardioprotection via the inhibition of $\mathrm{mPTP}$ opening by the activation of the ERK1/2-GSK-3 3 , PI3K-Akt-GSK-3 $\beta$ and PKC- $\varepsilon$-mitoK ATP pathways in aging cardiomyocytes. These findings provide a novel target for the treatment of aging ischemic cardiomyopathy.
\end{abstract}

Keywords: Hydrogen sulfide, Post-conditioning, Mitochondrial permeability transition pore, Aging cardiomyocytes

\section{Background}

Myocardial ischemia (hypoxia)/reperfusion (reoxygenation) causes cardiomyocyte injury, including cardiomyocyte apoptosis and necrosis. Free radical generation, calcium overload and the adhesion of leukocytes are the main mechanisms of ischemia/reperfusion (I/R) injury. In 1986, Murry et al. first reported that ischemic preconditioning (IPC) plays an important cardioprotective role against ischemia-induced injuries $[1,2]$. However,

\footnotetext{
*Correspondence: hongzhuli61@163.com; xucq45@126.com 1 Department of Pathophysiology, Harbin Medical University, Baojian Road, Harbin 150081, China

Full list of author information is available at the end of the article
}

IPC must be applied before the ischemic event, which is unpredictable, and is impractical in the clinical setting of acute myocardial infarction [3]. According to a similar regimen of brief periods of ischemia applied just after, instead of just before, sustained ischemia was shown to be as protective as preconditioning. In 2003, Zhao et al. [4] first proposed the concept of ischemic post-conditioning (PC). PC is defined as repetitive cycles of briefly interrupted reperfusion applied at the onset of establishing reflow and has been shown to significantly improve outcome following an episode of ischemia [4]. The main theories of PC-induced protection are the preservation of mitochondrial integrity via regulation of 
the mitochondrial permeability transition pore (mPTP) [2]. Inhibition of mPTP opening is considered to be the final step in a complex series of cellular signalling events preventing cell death [2]. It is thought that PC activates a signal transduction pathway involving the pro-survival kinases phosphatidylinositol-3-OH kinase (P13K) and protein kinase B (Akt) and the $\mathrm{p} 42 / \mathrm{p} 44$ extracellular signal-regulated kinases (ERK1/2), and it has been termed the reperfusion injury salvage kinase (RISK) pathway [59]. Meanwhile, $\mathrm{PC}$ also activates protein kinase $\mathrm{C}$ (PKC)mitochondrial ATP-sensitive potassium (mitoK $\mathrm{ATP}_{\text {) }}$ ) channels (PKC-mitoK ${ }_{\text {ATP }}$ pathway) [5, 9-11]. The RISK and PKC-mitoK $\mathrm{ATP}_{\text {ATP }}$ pathways terminate with the inhibition of mPTP opening at reperfusion, thus affording cardioprotection in PC $[2,12]$.

The degeneration, decrease of autophagic capacity and mitochondrial function (mtDNA mutation), increase of oxidative stress and reduced production of endogenous protective substances in ageing cardiomyocytes, leads to a weakening or disappearance of sensitivity of aging cardiomyocytes to PC $[13,14]$. Aging hearts are also resistant to the powerful endogenous protections provided by PC. In other words, PC loses its myocardial protective effect in aging hearts [15].

Hydrogen sulfide $\left(\mathrm{H}_{2} \mathrm{~S}\right)$ is a highly diffusible gasotransmitter that influences cellular and organ functions through a number of different mechanisms [16]. Endogenous production of $\mathrm{H}_{2} \mathrm{~S}$ is mainly catalysed by cystathionine $\beta$-synthase (CBS), cystathionine- $\gamma$-lyase (CSE) and 3-mercaptosulphurtransferase (3-MPST) [17]. CBS and CSE have been consistently shown to produce $\mathrm{H}_{2} \mathrm{~S}$ in mammalian tissues, with L-cysteine and/or homocysteine as the main substrate $[18,19]$. Recently, 3-MPST, which uses both L-cysteine and alpha ketoglutarate as substrates along with cysteine aminotransferase to produce $\mathrm{H}_{2} \mathrm{~S}$, was identified [20]. Among them, CSE is the major $\mathrm{H}_{2} \mathrm{~S}$-producing enzyme in vascular tissues. The abnormal metabolism and functions of the $\mathrm{CSE} / \mathrm{H}_{2} \mathrm{~S}$ pathway have been linked to various cardiovascular diseases, including $\mathrm{I} / \mathrm{R}$ injury, atherosclerosis, hypertension, and oxidative stress [21-26].

It was previously reported that $\mathrm{H}_{2} \mathrm{~S}$ is involved in PCinduced cardioprotection [21-26]. Our previous study indicated that exogenous $\mathrm{H}_{2} \mathrm{~S}$ recovered cardioprotection from $\mathrm{PC}$ in isolated aging rat hearts [27]. However, whether $\mathrm{H}_{2} \mathrm{~S}$ plays a key role in the recovery of PCinduced cardioprotection in aging cardiomyocytes is unknown. This study investigated the effect of exogenous $\mathrm{H}_{2} \mathrm{~S}$ on the recovery of PC-induced cardioprotection and its possible mechanisms, including the ERK1/2-GSK-3 $\beta$, PI3K-Akt-GSK- $3 \beta$ and PKC- $\varepsilon$-mitoK ATP $_{\text {pathways and }}$ mPTP opening, in aging cardiomyocytes.

\section{Methods}

\section{Drugs and reagents}

Sodium hydrogen sulfide (NaHS), the anti-CSE antibody, PD98059 (an inhibitor of ERK), LY294002 (a PI3K inhibitor), 5-hydroxydecanoate (5-HD, a $\mathrm{mK}_{\text {ATP }}$ inhibitor), Chelerythrine chloride (Che, a PKC inhibitor) were purchased from Sigma Chemical Co. (St. Louis, MO, USA). The primary antibodies for anti-PKC- $\varepsilon$, anti-cleaved caspase-3 and -9, Bcl-2, cytochrome $c$ (Cyt $c$ ), $\mathrm{Na}^{+} / \mathrm{K}^{+}$ATPase, cyclin D1, p21 ${ }^{\text {Cip/WAF-1 }}$ and GAPDH were from Santa Cruz (Bergheimer, Germany). Hoechst 33342, JC-1 kit and Calcein-AM were also from Santa Cruz. The antiERK1/2 and PI3K-Akt-GSK-3 $\beta$ antibodies were obtained from Cell Signaling Technology (Danvers, USA). Senescence $\beta$-galactosidase ( $\beta$-gal) staining kit was purchased from Beyotime Institute of Biotechnology (Shanghai, China). Rat advanced glycation end products (AGEs) ELISA kit was purchased from Proteintech Group (Wuhan, China). All other chemicals were from Sigma or Santa Cruz.

\section{Primary culture of cardiomyocytes}

Primary cultures of neonatal cardiomyocytes were prepared as previously described $[8,27]$. Newborn Wistar rats, aged 1-3 days and weighing 5-8 g, were used for this study. All animal experiments were conducted in compliance with the Guide for the Care and Use of Laboratory Animals published by the China National Institutes of Health and approved by the Animal Care Committees of Harbin Medical University, China. Briefly, cells were dissociated from minced hearts of 1- to 3-day neonatal Wistar rats with a $0.25 \%$ solution of crude trypsin. Cells were cultured as monolayers at a density of $5 \times 10^{4}$ cells $/ \mathrm{cm}^{2}$ in Dulbecco's modified Eagle medium (DMEM) equilibrated with humidified air containing 5\% $\mathrm{CO}_{2}$ at $37^{\circ} \mathrm{C}$. The medium contained $10 \%$ calf serum and $2 \mu \mathrm{M}$ fluorodeoxyuridine, the latter to prevent proliferation of non-myocytes.

\section{Aging of myocardial cells induced by D-galactose}

The treatment for D-galactose induction was as previously described $[28,29]$. Once the attached cardiomyocytes were beating spontaneously, the DMEM supplemented with $20 \%$ fetal calf serum was removed, and DMEM supplemented with different concentrations $(0,0.1,1,10,100 \mathrm{~g} / \mathrm{L}) \mathrm{D}$-galactose was added to the cardiomyocytes in the culture cluster for a further different incubation period $(0,12,24,48,72 \mathrm{~h})$. The degree of cell aging was observed through SA $\beta$-Gal Staining and AGEs ELISA Assay. In the present study, we selected $10 \mathrm{~g} / \mathrm{L}$ D-galactose concentrations for $48 \mathrm{~h}$ incubation period. 


\section{Established aging cardiomyocytes model of hypoxia/ reoxygenation}

A hypoxic condition was produced by D-Hank solution (in mM: $5.37 \mathrm{KCl}, 0.44 \mathrm{KH}_{2} \mathrm{PO}_{4}, 136.89 \mathrm{NaCl}, 4.166$ $\mathrm{NaHCO}_{3}, 0.338 \mathrm{Na}_{2} \mathrm{HPO}_{4}, 5$ D-glucose, $\mathrm{pH} 7.3-7.4$ at $37^{\circ} \mathrm{C}$ ) saturated with $95 \% \mathrm{~N}_{2}$ and $5 \% \mathrm{CO}_{2}$. The $\mathrm{pH}$ was regulated to 6.8 with lactate to mimic ischemic solution. The aging cardiomyocytes were put into a hypoxic incubator that was equilibrated with $1 \% \mathrm{O}_{2} / 5 \% \mathrm{CO}_{2} / 94 \% \mathrm{~N}_{2}$. After hypoxia, the culture medium was rapidly replaced with fresh DMEM with 10\% fetal bovine serum (normoxic culture solution) for initiating reoxygenation [9].

\section{Experimental protocols}

The aging cardiomyocytes were randomly divided into the following seven groups. Each group included eight samples $(\mathrm{n}=8)$ (Fig. 1): (1) control group (Control): the aging cardiomyocytes were cultured for $9 \mathrm{~h}$ with $10 \%$ fetal bovine serum-DMEM; (2) hypoxia/reoxygenation group $(\mathrm{H} / \mathrm{R})$ : the aging cardiomyocytes were exposed to hypoxic culture medium for $3 \mathrm{~h}$ and reoxygenated for $6 \mathrm{~h}$ by replacing the hypoxic culture medium with fresh DMEM with $10 \%$ fetal bovine serum; (3) $\mathrm{H} / \mathrm{R}+\mathrm{H}_{2} \mathrm{~S}$ group: the procedure was similar to that for group 2, except that $100 \mu \mathrm{M}$ NaHS were added in $6 \mathrm{~h}$ reoxygenation; (4) PC group: at the end of $3 \mathrm{~h}$ of hypoxia, the aging cardiomyocytes were exposed to normoxic culture solution for $5 \mathrm{~min}$, after which cells were placed in hypoxic solution for $5 \mathrm{~min}$. The $\mathrm{PC}$ cycle was repeated three times and followed by $6 \mathrm{~h}$ of reoxygenation; (5) $\mathrm{PC}+\mathrm{H}_{2} \mathrm{~S}$ group: at the end of $3 \mathrm{~h}$ of hypoxia, initiated immediately at the onset of reoxygenation, $100 \mu \mathrm{M}$ NaHS were given at the onset of reoxygenation for $5 \mathrm{~min}$ following with 5 min hypoxia. This protocol was repeated for another two times. The cells were then treated as those of group 3; (6) PC + PD98059 (or LY294002, or 5-HD, or Che) group: $10 \mu \mathrm{M}$ PD98059 (or $10 \mu \mathrm{M}$ LY294002 or $100 \mu \mathrm{M}$ 5 -HD or $100 \mu \mathrm{M}$ Che) were added to the medium $40 \mathrm{~min}$ before the end of hypoxia. The cells were then treated as those of group 4; (7) PC + PD98059 (or LY294002, or 5-HD, or Che) $+\mathrm{H}_{2} \mathrm{~S}$ group: $10 \mu \mathrm{M}$ PD98059 (or $10 \mu \mathrm{M}$ LY294002 or $100 \mu \mathrm{M} 5$-HD or $100 \mu \mathrm{M}$ Che) were added to the medium $40 \mathrm{~min}$ before the end of hypoxia. The cells were then treated as those of group 5.

The normal cultured cardiomyocytes (without D-galactose-treated cardiomyocytes) were randomly divided into three groups. Each group included eight samples $(\mathrm{n}=8)$ : Control group; H/R group; PC group. The cells were treated as those of group 1, 2 and 4, respectively.

\section{AGEs ELISA Assay}

The rat advanced glycation end products (AGEs) assay was performed with AGEs ELISA kit according to the instructions from the manufacturer and was as previously described $[29,30]$. The reagents of the test kit were placed at room temperature for $30 \mathrm{~min}$ and diluted 1:20 with distilled water. Aliquots of $100 \mu \mathrm{L}$ of the standards and samples were added to blank micropores and $50 \mu \mathrm{L}$ enzyme marker solution was added. Microtiter plates were incubated at $37^{\circ} \mathrm{C}$ for $60 \mathrm{~min}$ and then washed five times and put aside for 10-20 s each time. The A and B substrate solutions $(50 \mu \mathrm{L})$ were added into the microtiter plates for $15 \mathrm{~min}$ dark reactions at $37^{\circ} \mathrm{C}$. The reaction was terminated by the addition of $50 \mu \mathrm{L}$ stop solution, and the optical density (OD) at $450 \mathrm{~nm}$ was determined by an ultra microplate reader (Bio-Rad Laboratories, Hercules, CA, USA). An AGEs standard curve was generated and the AGEs values of the samples were calculated from the standard curve.

\section{SA $\beta$-Gal staining}

Senescence-associated $\beta$-gal (SA $\beta$-gal) activity was measured with the $\beta$-gal staining kit at $\mathrm{pH} 6.0$ according to the instructions from the manufacturer $[29,30]$. Briefly, the cells were washed in phosphate buffered saline (PBS), fixed for 10-15 min at room temperature with $1 \mathrm{~mL}$ of fixative solution and incubated overnight at $37^{\circ} \mathrm{C}$ with the staining solution mix. Cells were observed for development of the blue coloration with a microscope at a magnification of $400 \times$. Aging cardiomyocytes were assessed by counting the number of cells that displayed blue coloration.

\section{Observation of cell division index}

Briefly, the cells were washed in phosphate buffered saline (PBS) for three times, fixed for $30 \mathrm{~min}$ at room temperature with methanol:ice acetic acid (3:1) and incubated for $10 \mathrm{~min}$ with Giemsa. Cells were observed with a microscope at a magnification of $400 \times$. Five fields (at least 100 cells of each field) were randomly selected and the percentage of cell division was calculated.

\section{Detection of cell viability}

Cell viability was determined by the 3-(4,5-dimethylthiazol-2-yl)-2,5-diphenyltetrazolium bromide (MTT) assay, as described previously [9, 25,31]. Cells were cultured in 96-well plates. MTT (final concentration, $0.5 \mathrm{mg} / \mathrm{mL}$ ) was added to each well under sterile conditions, and the plates were incubated for $4 \mathrm{~h}$ at $37^{\circ} \mathrm{C}$. The supernatant was removed, and dimethyl sulfoxide $(150 \mu \mathrm{l} /$ well $)$ was added. The plates were then agitated on a plate shaker. The absorbance of each well was measured at $490 \mathrm{~nm}$ with a Bio-Rad automated EIA analyser (Bio-Rad Laboratories, Hercules, CA, USA). The viability of control cells was considered $100 \%$, and the others were expressed as percentages of control. 


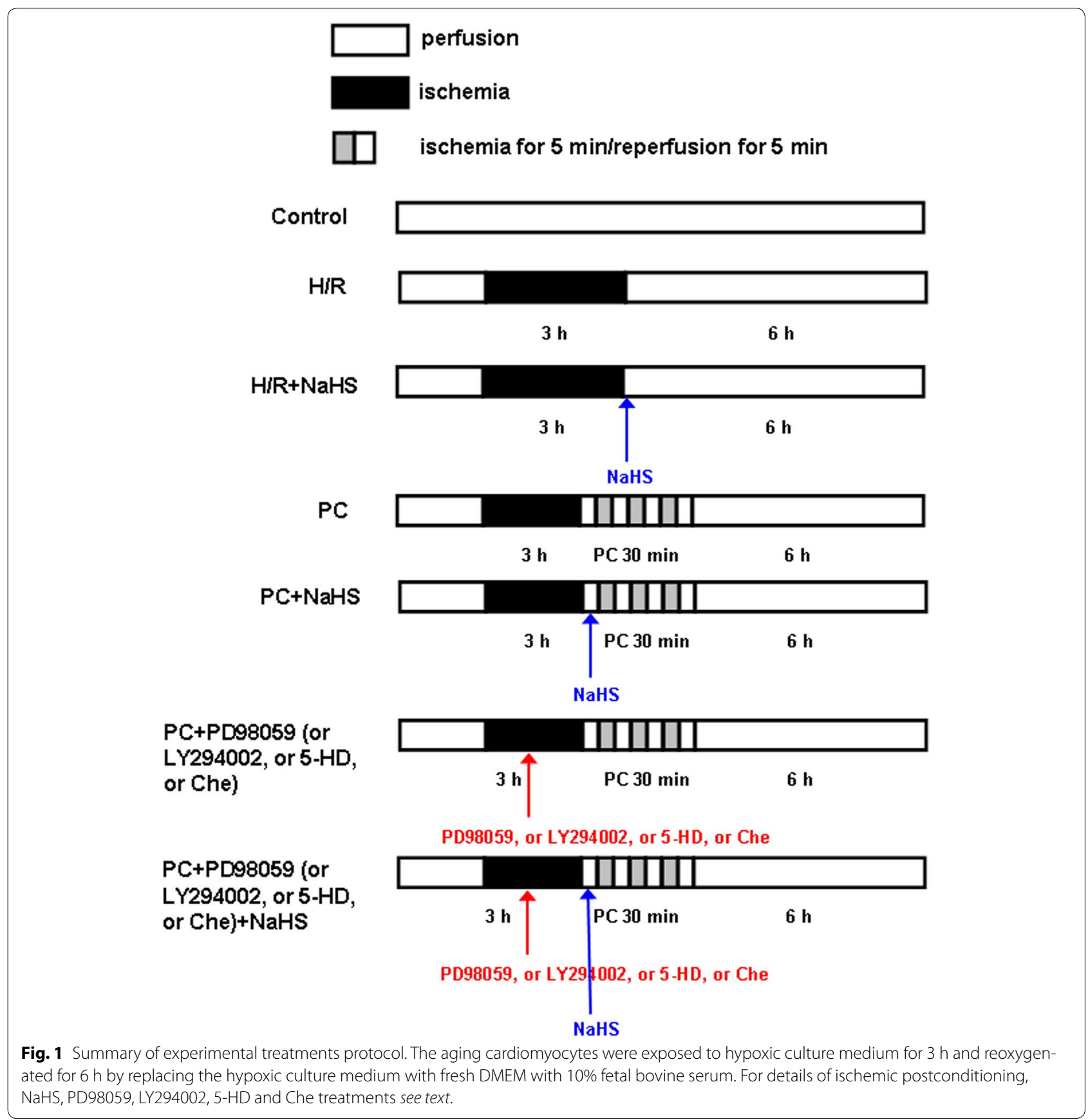

\section{Determination of $\mathrm{H}_{2} \mathrm{~S}$ production}

$\mathrm{H}_{2} \mathrm{~S}$ production rate was measured as described previously [25]. In brief, after different treatments, the $\mathrm{H} 9 \mathrm{C} 2$ cells (cardiomyocytes line) were collected and homogenized in $50 \mathrm{mM}$ ice-cold potassium phosphate buffer $(\mathrm{pH}$ 6.8). The flasks containing the reaction mixture (100 mM potassium phosphate buffer, $10 \mathrm{mM}$ L-cysteine, $2 \mathrm{mM}$ pyridoxal 5 -phosphate, and $10 \%$ cell homogenates) and center wells containing $0.5 \mathrm{~mL} 1 \%$ zinc acetate and a piece of filter paper $(2 \times 2.5 \mathrm{~cm})$ were flushed with $\mathrm{N}_{2}$ gas and incubated at $37^{\circ} \mathrm{C}$ for $90 \mathrm{~min}$. The reaction was stopped by adding $0.5 \mathrm{~mL}$ of $50 \%$ trichloroacetic acid, and the flasks were incubated at $37^{\circ} \mathrm{C}$ for another $60 \mathrm{~min}$. The contents of the center wells were transferred to test tubes, each containing $3.5 \mathrm{~mL}$ of water. Then $0.5 \mathrm{~mL}$ of $20 \mathrm{mM} \mathrm{N}, N$-dimethyl-p-phenylenediamine sulfate in $7.2 \mathrm{M} \mathrm{HCl}$ and $0.5 \mathrm{~mL} 30 \mathrm{mM} \mathrm{FeCl}_{3}$ in $1.2 \mathrm{M}$ $\mathrm{HCl}$ was added. The absorbance of the resulting solution 
at $670 \mathrm{~nm}$ was measured $20 \mathrm{~min}$ later with a FLUOstar OPTIMA microplate spectrophotometer.

\section{Apoptotic rate of cells by flow cytometry assay}

The apoptotic rate was measured by flow cytometry as described previously $[9,28,31]$. Cells were washed three times with ice-cold PBS, and then stained with annexin V-fluorescein isothiocyanate for $15 \mathrm{~min}$ at room temperature in $200 \mu \mathrm{l}$ binding buffer. Next, $300 \mu \mathrm{l}$ binding buffer was added, and the cells were stained with propidium iodide for $30 \mathrm{~min}$ at $4^{\circ} \mathrm{C}$. The fluorescence of the cells was analyzed by flow cytometry. The percentage of apoptotic cells was determined using Mod Fit LT software (Verity Software House Inc., Topsham, ME, USA).

\section{Hoechst 33342 staining}

Cells were analyzed for apoptosis after visualization of nuclei morphology with fluorescent DNA-binding dye Hoechst 33342, as described previously [9]. After treatment, cells were rinsed with PBS and incubated with $5 \mu \mathrm{g} / \mathrm{mL}$ Hoechst 33342 for $10 \mathrm{~min}$. Nuclei were visualized at 400× magnification using fluorescent microscopy (Nikon Corporation, Tokyo, Japan) at an excitation wavelength of 330-380 nm. Apoptotic nuclei of cells were assessed by counting the number of cells that displayed nuclear morphology changes, such as chromatin condensation and fragmentation.

\section{Real-time PCR analysis}

Total RNA was isolated using an RNeasy Mini Kit (Qiagen, Germantown, MD, USA) and converted to CDNA with an iScriptTM cDNA Synthesis Kit (Bio-Rad, Hercules, CA, USA). Real-time PCR was performed in an iCycler iQ5 apparatus (Bio-Rad) associated with the iCycler optical system software (version 3.1) using SYBR Green PCR Master Mix. The primers of Bcl-2 were 5'-GGCATCTTCTCCT TCCAG-3' (forward) and 5'-CATCCCAGCCTCCGT TAT-3' (reverse). Caspase-3 primers were 5'-CAGACAGTGGAACTGACGATGA-3' (forward) and 5'-AACAGAA ACATGCCCCTACCCC-3' (reverse). Caspase-9 primers were $5^{\prime}$-CCCGTGAAGCAAGGATTT- $3^{\prime}$ (forward) and 5'-ACTGTGGGTCTGGGAAGC-3' (reverse). P-ERK1/2 primers were $5^{\prime}$-ATCCCCCATGGAACGACCTG-3' (forward) and 5'-ACCCGCCAGGGACAAAAATG- ${ }^{\prime}$ (reverse). The primers of p-PI3K were $5^{\prime}$-CCCTTCTG AACTGGCTTAAAGA-3' (forward) and 5'-GGACAGTG TAAATTCCTCAATGG- $3^{\prime}$ (reverse). The primers for p-Akt were $5^{\prime}$-TGTGACCATGAACGAGTTTGA-3' (forward) and 5'-GTCGTGGGTCTGGAATGA-3' (reverse). P-GSK-3 $\beta$ primers were 5'-CGGGACCCAAATGTCA AACA-3' (forward) and 5'-CGTGACCAGTGTTGCTG AGT-3' (reverse). The primers of PKC- $\varepsilon$ were $5^{\prime}$-CATGGA AGGATAAGCGTTGGT-3' (forward) and 5'-CCCA
AGTCCCGTGTTAAGA-3' (reverse). The primers for GAPDH were 5'-CTCAACTACATGGTCTACATG-3' (forward) and $5^{\prime}$-TGGCATGGACTGTGGTCATGAG- ${ }^{\prime}$ (reverse). The cycling conditions were: one cycle of $94^{\circ} \mathrm{C}$ for $2 \mathrm{~min} ; 30$ cycles of $94^{\circ} \mathrm{C}$ for $30 \mathrm{~s}, 60^{\circ} \mathrm{C}$ for $40 \mathrm{~s}$ and $72^{\circ} \mathrm{C}$ for $1 \mathrm{~min}$; and $72^{\circ} \mathrm{C}$ for $4 \mathrm{~min}$. Relative mRNA quantification was calculated by using the arithmetic formula " $2-\Delta \Delta C T$ ", where $\Delta \mathrm{CT}$ is the difference between the threshold cycle of a given target cDNA and an endogenous reference GAPDH cDNA.

\section{Detection of Cyt $c$ release from mitochondrial}

Western blot analysis of Cyt $c$ in the cytosolic fraction was performed as described previously $[9,25,28,31]$. Briefly, cells were harvested, washed twice with icecold PBS, and incubated in ice-cold Tris-sucrose buffer (0.35 mM sucrose, $10 \mathrm{mM}$ Tris- $\mathrm{HCl}$ at $\mathrm{pH} 7.5,1 \mathrm{mM}$ EDTA, $0.5 \mathrm{mM}$ dithiothreitol, $0.1 \mathrm{mM}$ phenylmethylsulphonyl fluoride). After a $40 \mathrm{~min}$ incubation, cells were centrifuged at $1,000 \times g$ for $5 \mathrm{~min}$ at $4^{\circ} \mathrm{C}$ and the supernatant was further centrifuged at $40,000 \times g$ for $30 \mathrm{~min}$ at $4^{\circ} \mathrm{C}$. The supernatant was retained as the cytosolic fraction and analyzed by Western blot with a primary rat anti-Cyt $c$ monoclonal antibody and a secondary goat anti-rat immunoglobulin G (Promage). GAPDH expression was used as the control.

\section{Translocation of PKC- $\varepsilon$}

Cardiomyocytes were lysed immediately after different treatment by resuspending in lysis buffer $[50 \mathrm{mM}$ Tris-HCl, pH 8.0, $150 \mathrm{mM} \mathrm{NaCl}, 5 \mathrm{mM}$ EDTA, 1\% Triton $\mathrm{X}-100,0.26 \%$ sodium deoxycholate, $50 \mathrm{mM}$ sodium fluoride, $10 \mathrm{mM} \beta$-glycerophosphate, $0.1 \mathrm{mM}$ sodium orthovanadate, $10 \mu \mathrm{g} / \mathrm{mL}$ leupeptin, and $1 \mathrm{mM}$ phenylmethylsulfonyl fluoride (PMSF)] and incubating on ice for $20 \mathrm{~min}$. Cell debris and insoluble material were cleared by centrifugation at $10,000 \times g$ for $10 \mathrm{~min}$. The supernatant is called the detergent-solubilized cell lysate. For the preparation of membrane-enriched fractions and subcellular fractions, cells were resuspended in $25 \mathrm{mM}$ Tris- $\mathrm{HCl}, \mathrm{pH} 7.5,250 \mathrm{mM}$ sucrose, $5 \mathrm{mM}$ $\mathrm{MgCl}_{2}, 100 \mathrm{mM} \mathrm{KCl}, 10 \mu \mathrm{g} / \mathrm{mL}$ each of aprotinin and leupeptin, and $1 \mathrm{mM} \mathrm{PMSF}$. Cells were disrupted by Dounce homogenization and fractionated by differential velocity centrifugation as previously described [7, 9]. Cell membrane fractions were analyzed by Western blotting with primary rabbit polyclonal isoform specific anti-PKC- $\varepsilon$ and secondary goat anti-rat IgG. $\mathrm{Na}^{+} / \mathrm{K}^{+}-$ ATPase was used a membrane fractions loading control. The volume of protein bands was quantified using a Bio-Rad Chemi DocTM EQ densitometer and Bio-Rad Quantity One software (Bio-Rad Laboratories, Hercules, USA). 


\section{Measurement of mitochondrial membrane potential}

$(\Delta \psi \mathrm{m})$

Changes in mitochondrial transmembrane potential $(\Delta \psi \mathrm{m})$ were measured with the dye $5,5^{\prime}, 6,6^{\prime}$-tetrachloro$1,1^{\prime}, 3,3^{\prime}$-tetraethylbenzimidazolcarbocyanine iodide (JC1). Mitochondrial membrane potential was determined as previously described [9]. Briefly, neonatal rat cardiomyocytes $\left(2.5 \times 10^{5}\right.$ cells $/ 60 \mathrm{~mm}^{2}$ dishes $)$ were seeded, incubated, and treated for $48 \mathrm{~h}$ at $37^{\circ} \mathrm{C}$. After experimentation, cells were stained with $\mathrm{JC}-1(2 \mu \mathrm{g} / \mathrm{mL}$, Invitrogen $)$ at $37^{\circ} \mathrm{C}$ in the dark for $15 \mathrm{~min}$ and rinsed three times with cold PBS. Observations were made using a Zeiss LSM 510 inverted confocal scanning microscope. JC-1 monomer (green) fluorescence was observed by excitation with $514 \mathrm{~nm}$ and examination of emission at $529 \mathrm{~nm}$. JC-1 aggregate (red) fluorescence was observed by examination of emission at 585/590 $\mathrm{nm}$. At least 100 areas were selected from each image, and the average intensity for each region was quantified. The ratio of JC-1 aggregate to monomer (red/green) intensity for each region was calculated. A decrease in this ratio was interpreted as decrease of $\Delta \psi \mathrm{m}$, whereas an increase in this ratio was interpreted as gain in $\Delta \psi \mathrm{m}$.

\section{Assay of mitochondrial permeability transition pore (mPTP) opening}

Changes of mitochondrial permeability transition pore (mPTP) opening were measured with coincubation of calcein-AM and cobalt chloride as previously described $[9,32]$. Cardiomyocytes were plated in 24-well plates $\left(0.5 \times 10^{6}\right.$ cells/well $)$. After different the treatments, the cells were loaded with calcein-AM $2 \mu \mathrm{M}$ in presence of $5 \mathrm{mM}$ of cobalt chloride in the dark for for $15 \mathrm{~min}$ at $37^{\circ} \mathrm{C}$. Fluorescence was measured in a Zeiss LSM 510 inverted confocal scanning microscope at $488 \mathrm{~nm}$ excitation and $505 \mathrm{~nm}$ emission. Fluorescence intensity of individual cells was measured using SigmaScan Pro 5 software. The fluorescence intensity in control group was considered $100 \%$ viable.

\section{Western blotting analysis}

Cells were homogenized in ice-cold lysis buffer containing $50 \mathrm{mM}$ Tris- $\mathrm{HCl}(\mathrm{pH}, 8.0), 150 \mathrm{Mm} \mathrm{NaCl}, 5 \mathrm{mM}$ EDTA, $1 \%$ Triton X-100, $0.26 \%$ sodium deoxycholate, $50 \mathrm{mM}$ sodium fluoride, $10 \mathrm{mM} \beta$-glycerophosphate, $0.1 \mathrm{mM}$ sodium orthovanadate, $10 \mu \mathrm{g} / \mathrm{mL}$ leupeptin, and $50 \mu \mathrm{g} / \mathrm{mL}$ phenylmethylsulfonyl fluoride (PMSF), and incubated on ice for $40 \mathrm{~min}$. The homogenate was centrifuged at $15,000 \times g$ for $15 \mathrm{~min}$ at $4^{\circ} \mathrm{C}$ to remove cellular debris and isolate total protein. Protein concentrations were determined using a Bradford assay kit (Bio-Rad Laboratories; Hercules, USA). Equal amounts of proteins were boiled and separated with SDS-PAGE and electrophoretically transferred to a nitrocellulose membrane, as described previously $[9,25]$. In each lane of a $10 \%$ sodium dodecyl sulfate-polyacrylamide gel electrophoresis, equal amounts of proteins were applied, electrophoresed and transferred to a polyvinylidene fluoride membrane. Membranes were blocked with Tris-buffered saline containing $5 \%$ non-fat milk at room temperature for $1 \mathrm{~h}$, then incubated overnight at $4^{\circ} \mathrm{C}$ with primary antibody. The primary antibody dilutions were $1: 1,000$ for CSE, phosphorylated or total ERK1/2, PI3K, Akt or GSK-3 $\beta$, and 1:500 for Bcl-2, cleaved caspase-3 and -9, GAPDH, $\mathrm{Na}^{+}-\mathrm{K}^{+}$-ATPase, cyclin D1 and $\mathrm{p} 21^{\mathrm{Cip} / \mathrm{WAF}-1}$. The membrane was then washed three times with $1 \times$ Tris-buffer saline-Tween 20 (TBST) buffer and incubated in TBST solution with horseradish peroxidase-conjugated secondary antibody (diluted 1:500) for $1 \mathrm{~h}$ at room temperature on a shaker. Finally, the membrane was washed with TBST solution for three times. Antibodyantigen complexes were detected using Western Blue Stabilized Substrate for alkaline phosphatase. GAPDH expression was used as the control. The intensities of the protein bands were quantified by a Bio-Rad ChemiDoc ${ }^{\mathrm{TM}}$ EQ densitometer and Bio-Rad Quantity One software (Bio-Rad Laboratories).

\section{Statistical analysis}

All data were expressed as the mean \pm SE and represented at least three independent experiments. Statistical comparisons were made using student's $t$ test or one-way ANOVA followed by a post hoc analysis (Tukey test) where applicable. Significance level was set at $\mathrm{p}<0.05$.

\section{Results}

PC plays cardioprotection in primary cultured neonatal cardiomyocytes

To observe the protective role of $\mathrm{PC}$ on the H/R-induced injury in primary cultured neonatal cardiomyocytes, we detected cell viability, cell apoptosis, mRNA level of caspase-3, caspase-9 and Bcl-2. Our data showed that $H / R$ decreased cell viability $(p=0.0003)$, increased the percentage of apoptotic cells $(\mathrm{p}=0.0008)$ and mRNA level of caspase-3 ( $\mathrm{p}=0.0006)$, caspase- $9(\mathrm{p}=0.0001)$ and Bcl-2 ( $\mathrm{p}=0.0002)$ compared with control group $(\mathrm{p}<0.05)$. Compared with $\mathrm{H} / \mathrm{R}$ group, $\mathrm{PC}$ increased cell viability $(\mathrm{p}=0.0005)$ and $\mathrm{Bcl}-2$ mRNA level $(\mathrm{p}=0.0007)$, decreased the percentage of apoptotic cells $(p=0.0007)$ and mRNA level of caspase- $3(\mathrm{p}=0.0003)$ and caspase- 9 $(\mathrm{p}=0.0009)(\mathrm{p}<0.05)$, suggesting that $\mathrm{PC}$ decreased apoptosis by H/R (Additional file 1: Figures S1, S2).

\section{D-Galactose induces aging in cardiomyocytes}

To investigate whether $\mathrm{D}$-galactose successfully induces the aging phenotype in cardiomyocytes, we examined 
the AGE content, which is considered to be an important marker of cardiac aging. Our results showed that incubation of cardiomyocytes with $10 \mathrm{~g} / \mathrm{L} \mathrm{D}$-galactose for $48 \mathrm{~h}$ significantly increased the AGE content compared with other all groups. Cell viability was not changed by treating the cells with $10 \mathrm{~g} / \mathrm{L} \mathrm{D}$-galactose for $48 \mathrm{~h}$ (Table 1 ).

To further confirm this phenomenon, we performed SA $\beta$-Gal staining and evaluated the $\mathrm{H} 9 \mathrm{C} 2$ cell division index (primary cultured neonatal cardiomyocytes do not divide) and the expression of cyclin D1 and p $21^{\mathrm{Cip} /}$ WAF-1. We found that the number of SA $\beta$-gal-positive cardiomyocytes and the expression of $\mathrm{p} 21^{\mathrm{Cip} / \mathrm{WAF}-1}$ were significantly increased while the $\mathrm{H} 9 \mathrm{C} 2$ cell division index and cyclin D1 expression were markedly decreased after incubation with $10 \mathrm{~g} / \mathrm{L} \mathrm{D}$-galactose for $48 \mathrm{~h}$ (p < $0.05 \mathrm{vs}$ $0 \mathrm{~g} / \mathrm{L} \mathrm{D}$-galactose for $48 \mathrm{~h}$ group) (Fig. 2).

\section{$\mathrm{H}_{2} \mathrm{~S}$ production rate and CSE expression changes using the D-galactose age-induced cardiomyocytes}

$\mathrm{CSE}$ is a $\mathrm{H}_{2} \mathrm{~S}$-producing key enzyme in the cardiovascular system. In order to detect whether the loss of PC cardioprotection in the aging cardiomyocytes may be related with the decrease of endogenous $\mathrm{H}_{2} \mathrm{~S}$, we examined $\mathrm{H}_{2} \mathrm{~S}$ production rate and CSE expression changes using D-galactose age-induced cardiomyocytes and H9C2 cells. Compared with the control group, the $\mathrm{H}_{2} \mathrm{~S}$ production rate $(\mathrm{p}=0.0004)$ and CSE expression (CSE-C: $\mathrm{p}=0.006$; CSE-H: $\mathrm{p}=0.004)(\mathrm{CSE}-\mathrm{C}$, primary cultures of neonatal cardiomyocytes; CSE-H, H9C2 cells) were significantly decreased in both the H/R and PC groups $(\mathrm{p}<0.05)$. The difference in the $\mathrm{H}_{2} \mathrm{~S}$ production rate and CSE expression

Table 1 The AGEs content and cell viability of different concentrations of $\mathrm{D}$-galactose for different times

\begin{tabular}{lcc}
\hline & AGEs content $(\mathbf{p g} / \mathbf{m L})$ & Cell viability (\%) \\
\hline D-Galactose concentration $(\mathrm{g} / \mathrm{L})^{\mathrm{a}}$ & \\
0 & $88 \pm 13$ & $100 \pm 23$ \\
0.1 & $191 \pm 22^{*}$ & $92 \pm 12$ \\
1 & $389 \pm 90^{*}$ & $93 \pm 34$ \\
10 & $924 \pm 93^{*}$ & $95 \pm 18$ \\
100 & $230 \pm 45^{*}$ & $93 \pm 26$ \\
Time $(\mathrm{h})^{\mathrm{b}}$ & & \\
0 & $95 \pm 12$ & $100 \pm 13$ \\
12 & $448 \pm 82^{*}$ & $94 \pm 21$ \\
24 & $577 \pm 75^{*}$ & $91 \pm 19$ \\
48 & $939 \pm 79^{*}$ & $96 \pm 25$ \\
72 & $668 \pm 102^{*}$ & $93 \pm 18$ \\
\hline
\end{tabular}

a The AGEs content and cell viability of different concentrations of $D$-galactose for $48 \mathrm{~h} .{ }^{*} \mathrm{p}<0.05$ vs. $0 \mathrm{~g} / \mathrm{L} \mathrm{D}$-galactose group.

b The AGEs content and cell viability of $10 \mathrm{~g} / \mathrm{L} \mathrm{D}$-galactose for different times. All data were from eight independent experiments. ${ }^{*} p<0.05$ vs. $0 \mathrm{~h}$ group. between the $H / R$ and $P C$ groups was not significant (Fig. 3).

\section{Exogenous $\mathrm{H}_{2} \mathrm{~S}$ increases cell viability and decreases} apoptosis in the D-galactose age-induced primary cultured neonatal cardiomyocytes

To assay whether exogenous $\mathrm{H}_{2} \mathrm{~S}$ restores $\mathrm{PC}$-induced cardioprotection, we observed cell viability through MTT mothed in the D-galactose age-induced cardiomyocytes. Cell viability was markedly reduced in the $\mathrm{H} / \mathrm{R}$ group and could be reversed by NaHS co-treatment. The cell viability of the PC group was similar to the H/R group. Compared with the H/R + NaHS and PC groups, cell viability was obviously increased in the $\mathrm{PC}+\mathrm{NaHS}$ group ( $\mathrm{p}=0.003, \mathrm{p}<0.05$ ), indicating that exogenous $\mathrm{H}_{2} \mathrm{~S}$ restored the $\mathrm{PC}$-induced increase in cell viability (Fig. 4a).

To investigate whether exogenous $\mathrm{H}_{2} \mathrm{~S}$ protects against PC-induced cardiac apoptosis, we examined cardiomyocyte apoptosis by flow cytometry. H/R significantly increased the percentage of apoptotic cells ( $\mathrm{p}=0.0003, \mathrm{p}<0.05$ vs. control group). Compared with the $H / R$ group, $H / R+N a H S$ reduced the apoptotic rate $(\mathrm{p}=0.0006, \mathrm{p}<0.05)$. The apoptotic rate of the PC group was similar to the $H / R$ group. The percentage of apoptotic cells in the $\mathrm{PC}+\mathrm{NaHS}$ group was significantly decreased compared with the H/R + NaHS and PC groups ( $\mathrm{p}=0.005, \mathrm{p}<0.05$ ) (Fig. 4b). We further looked for the morphological changes in the nuclei of cardiomyocytes with Hoechst 33342. The number of apoptotic nuclei showing the typical features of fragmentation and condensation in the $H / R$ group was significantly increased compared to the control group ( $\mathrm{p}=0.0003$, $\mathrm{p}<0.05)$. The number of apoptotic nuclei was significantly decreased in the $\mathrm{H} / \mathrm{R}+\mathrm{NaHS}$ group compared with that in the $H / R$ group $(p=0.0002, p<0.05)$. The number of apoptotic nuclei in the PC group was similar to the H/R group. Compared with the H/R + NaHS and $\mathrm{PC}$ groups, the number of apoptotic nuclei was significantly decreased in the PC + NaHS group $(\mathrm{p}=0.009$, $\mathrm{p}<0.05$ ), suggesting that exogenous $\mathrm{H}_{2} \mathrm{~S}$ prevented $\mathrm{PC}$ inhibited apoptosis by H/R (Fig. 4c).

\section{Exogenous $\mathrm{H}_{2} \mathrm{~S}$ inhibits pro-apoptotic factors} and promotes anti-apoptotic factors in the D-galactose age-induced primary cultured neonatal cardiomyocytes $\mathrm{H} / \mathrm{R}$ damages mitochondria, then the release of proapoptotic factors (cleaved caspase-3, cleaved caspase- 9 and Cyt $c$ ) from injured mitochondria is increased, which finally lead to apoptosis. To further indicate exogenous $\mathrm{H}_{2} \mathrm{~S}$ restores $\mathrm{PC}$-induced cardioprotection via inhibition of apoptosis, we examined the expression of cleaved caspase-3, cleaved caspase- 9 and Bcl- 2 in the whole cell 
a

b

$0 \mathrm{~g} / \mathrm{L}$ D-galactose for $48 \mathrm{~h}$

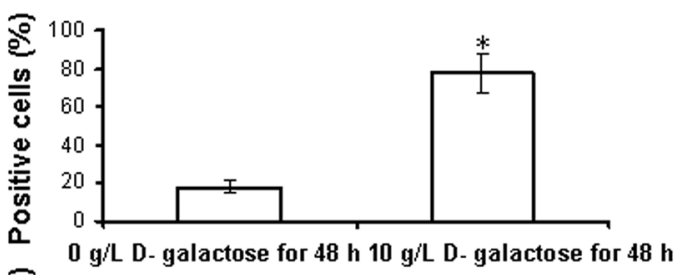

홍
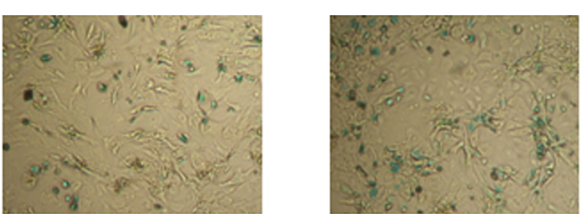

$10 \mathrm{~g} / \mathrm{L} \mathrm{D}$ - galactose for $48 \mathrm{~h}$

C

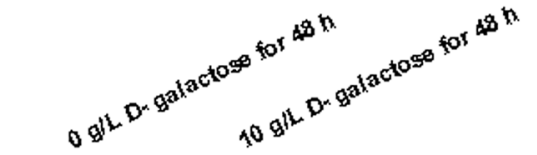

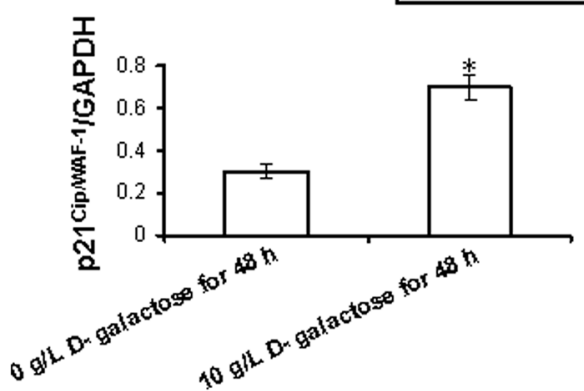

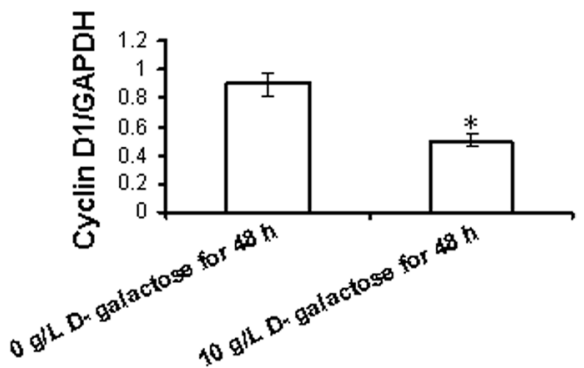

Fig. 2 Response of neonatal rat cardiomyocytes to $10 \mathrm{~g} / \mathrm{L}$ D-galactose for $48 \mathrm{~h}$. a The number of SA $\beta$-gal-positive cardiomyocytes. Phase-contrast images showing morphologic changes and stained cells. (SA- $\beta$-gal positive cells; Blue, magnification $\times 400)$. The aging cardiomyocytes in at least five random fields were counted. $\mathbf{b} \mathrm{H} 9 \mathrm{C} 2$ cells division index. Five fields (at least 100 cells of each field) were randomly selected and the percentage of cell division was calculated. cThe expression of $\mathrm{p}_{21}^{\mathrm{Cip} / \mathrm{WAF}-1}$ and cyclin D1. The intensity of each band was quantified by densitometry, and data were normalized to the GAPDH signal. All data were from four independent experiments. ${ }^{*} \mathrm{p}<0.05 \mathrm{vs}$. $0 \mathrm{~g} / \mathrm{L} \mathrm{D}$-galactose for $48 \mathrm{~h}$ group.

lysates as well as Cyt $c$ in the cytosolic fraction by western blot in the D-galactose age-induced cardiomyocytes.

Figure 5 shows that the expression of cleaved caspase- 3 $(\mathrm{p}=0.0009)$, cleaved caspase-9 $(\mathrm{p}=0.0007)$ and Cyt $c$ $(\mathrm{p}=0.0005)$ and Bcl-2 ( $\mathrm{p}=0.0004)$ was increased in the $\mathrm{H} / \mathrm{R}$ group compared with the control group $(\mathrm{p}<0.05)$. Compared with H/R, H/R + NaHS showed decreased expression of cleaved caspase-3 $(\mathrm{p}=0.004)$, cleaved caspase-9 $(\mathrm{p}=0.009)$ and Cyt $c(\mathrm{p}=0.008)$ but increased expression of Bcl-2 ( $\mathrm{p}=0.0007)(\mathrm{p}<0.05)$. The results of the PC group were similar to those of the H/R group. $\mathrm{PC}+\mathrm{NaHS}$ treatment markedly decreased the expression of cleaved caspase- $3(\mathrm{p}=0.004)$, cleaved caspase- 9 $(\mathrm{p}=0.009)$ and Cyt $c(\mathrm{p}=0.0008)$ and increased the expression of Bcl-2 $(\mathrm{p}=0.0007)$ in comparison with the $\mathrm{H} / \mathrm{R}+\mathrm{NaHS}$ and $\mathrm{PC}$ groups $(\mathrm{p}<0.05)$. These results 


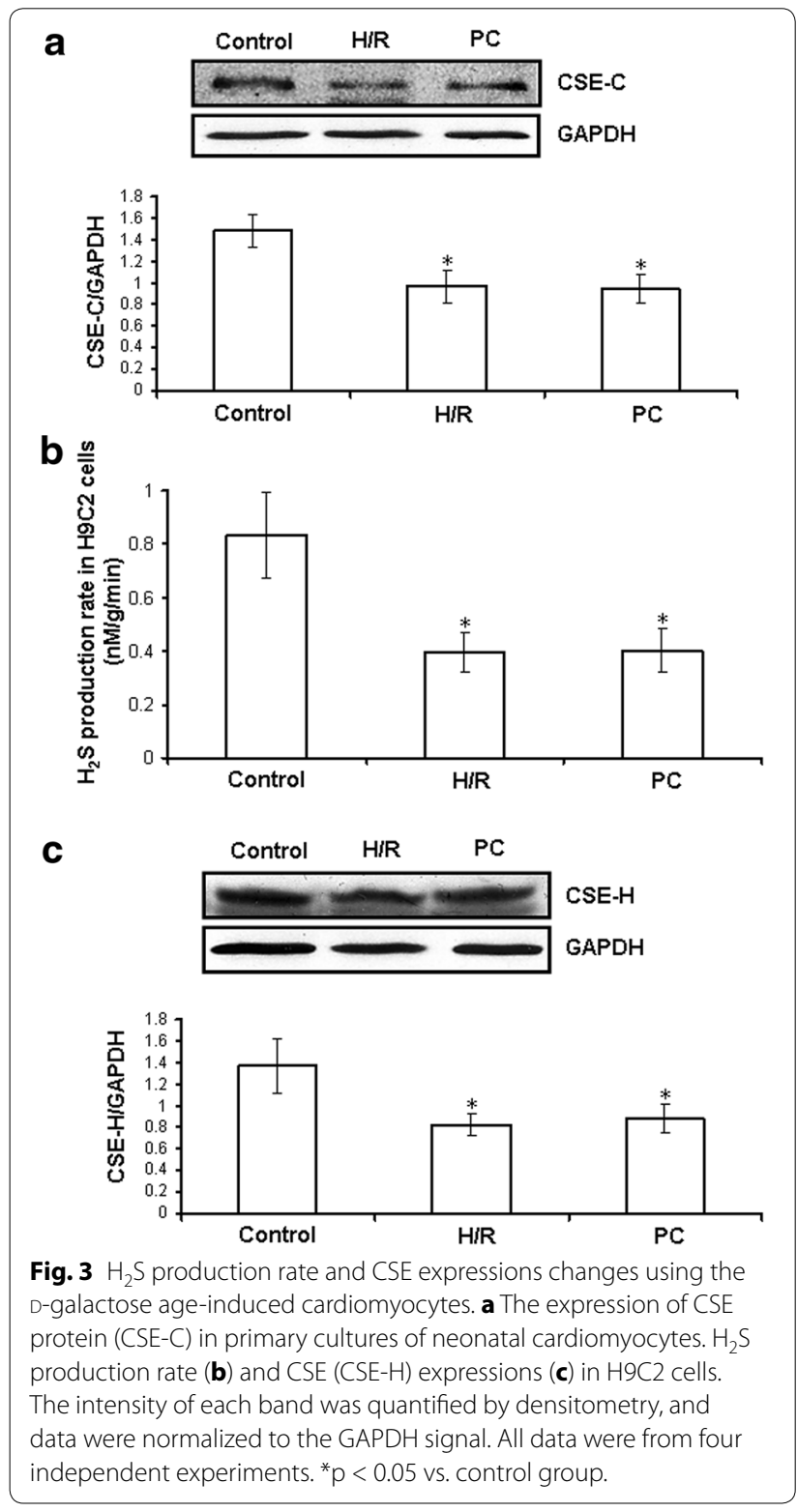

suggest that exogenous $\mathrm{H}_{2} \mathrm{~S}$ restores the anti-apoptotic effect of $\mathrm{PC}$ against $\mathrm{H} / \mathrm{R}$ by preventing the mitochondrial apoptotic pathway (Cyt $c$-caspase-9-caspase-3).

\section{Exogenous $\mathrm{H}_{2} \mathrm{~S}$ up-regulates ERK1/2-GSK-3 $\beta$} and PI3K-Akt-GSK-3 $\beta$ pathways in the D-galactose age-induced primary cultured neonatal cardiomyocytes ERK1/2-GSK-3 $\beta$ and PI3K-Akt-GSK-3 $\beta$ pathways play an important role in the cellular metabolism and gene expression related to growth and apoptosis. To detect whether exogenous $\mathrm{H}_{2} \mathrm{~S}$ restores $\mathrm{PC}$ protective role by activating ERK1/2-GSK-3 $\beta$ and PI3K-Akt-GSK-3 $\beta$ pathways, we observed the mRNA level and activity of phosphorylated ERK1/2, GSK-3 $\beta$, PI3K and Akt in the D-galactose age-induced cardiomyocytes.

The activity and the mRNA level of phosphorylated ERK1/2 $(\mathrm{p}=0.0005)$ and GSK-3 $\beta(\mathrm{p}=0.0003)$ in the $\mathrm{H} / \mathrm{R}$ group was significantly lower than that in the control group $(\mathrm{p}<0.05)$. The activity and the mRNA level of phosphorylated ERK1/2 $(\mathrm{p}=0.0009)$ and GSK-3 $\beta$ ( $p=0.0004$ ) was significantly higher in the $H / R+N a H S$ group than in the $H / R$ group $(p<0.05)$. The changes in phosphorylated ERK1/2 and GSK-3 $\beta$ activities and mRNA levels in the PC group were similar to those in the $\mathrm{H} / \mathrm{R}$ group. In the $\mathrm{PC}+\mathrm{NaHS}$ group, the activity and the mRNA level of phosphorylated ERK1/2 $(\mathrm{p}=0.004)$ and GSK-3 $\beta(p=0.006)$ was increased to a larger extent than that in the $\mathrm{H} / \mathrm{R}+\mathrm{NaHS}$ and PC groups $(\mathrm{p}<0.05)$, but an ERK1/2 inhibitor (PD98059) abolished these effects of NaHS. The total amount of ERK1/2 and GSK-3 $\beta$ protein remained unchanged with the different stimulations. These data demonstrate that exogenous $\mathrm{H}_{2} \mathrm{~S}$ restores the cardioprotection of $\mathrm{PC}$ through the activation of the ERK1/2-GSK-3 $\beta$ pathway (Fig. 6; Additional file 1: Figure S3).

Figure 7 and Additional file 1: Figure S4 showed that the activity and the mRNA level of phosphorylated PI3K

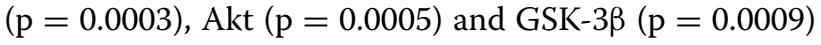
were decreased in the $H / R$ group compared with those in the control group $(\mathrm{p}<0.05)$. The activity and the mRNA level of PI3K ( $p=0.0008)$, Akt $(p=0.0004)$ and GSK-3 $\beta$ $(\mathrm{p}=0.0006)$ was increased in the $\mathrm{H} / \mathrm{R}+\mathrm{NaHS}$ group compared with that in the H/R group $(\mathrm{p}<0.05)$. Their changes in the PC group were similar to the H/R group. $\mathrm{PC}+\mathrm{NaHS}$ significantly increased the activity and the mRNA level of PI3K ( $\mathrm{p}=0.008)$, Akt $(\mathrm{p}=0.003)$ and GSK-3 $\beta(p=0.007)$ in comparison with the H/R + NaHS and PC groups $(\mathrm{p}<0.05)$, and an inhibitor of PI3K (LY294002) significantly suppressed the NaHS-induced phosphorylation of PI3K, Akt and GSK-3 $\beta$. The total amount of PI3K, Akt and GSK-3 $\beta$ protein remained unchanged with different stimulations. These results suggest that exogenous $\mathrm{H}_{2} \mathrm{~S}$ restored the protective effects of PC by the up-regulation of the PI3K-Akt-GSK-3 $\beta$ pathway.

\section{Exogenous $\mathrm{H}_{2} \mathrm{~S}$ promotes translocation of PKC- $\varepsilon$ to the cell membrane in the $\mathrm{D}$-galactose age-induced primary cultured neonatal cardiomyocytes}

The PKC- $\varepsilon$ activates the $\mathrm{mK}_{\mathrm{ATP}}$ and then inhibits mPTP opening, which finally plays protection during PC. In this study, we examined the translocation of PKC- $\varepsilon$ in the cell membrane. Our results demonstrated that the novel PKC- $\varepsilon$ isoform is activated by NaHS. Figure 8 and Additional file 1: Figure $S 5$ showed that $\mathrm{PKC}-\varepsilon$ translocated to the cell membrane in the H/R + NaHS and PC + NaHS 
a

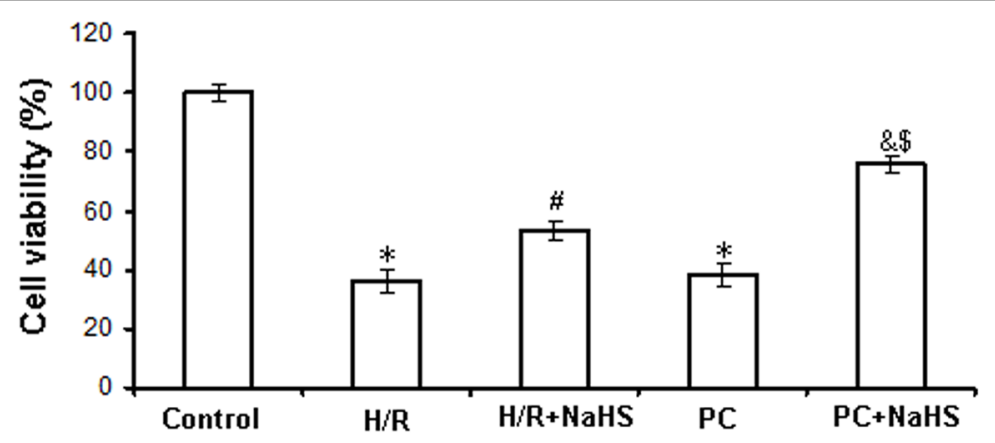

b

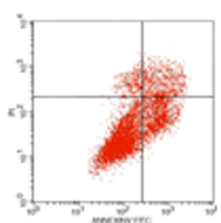

Control

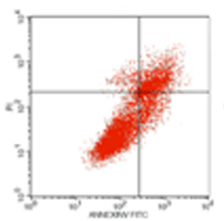

H/R

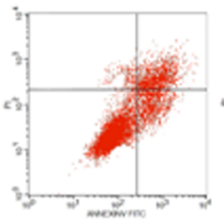

$\mathrm{H} / \mathrm{R}+\mathrm{NaHS}$

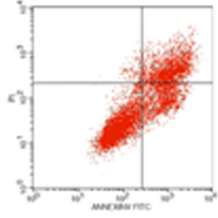

PC

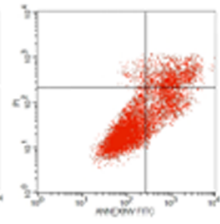

$\mathrm{PC}+\mathrm{NaHS}$

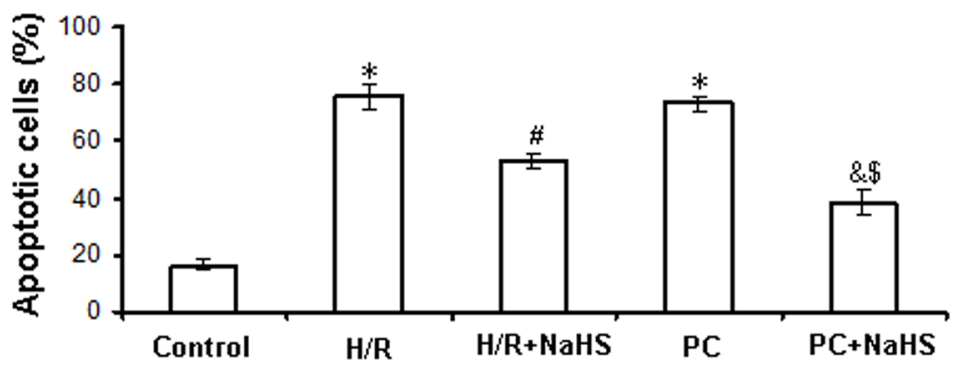

C

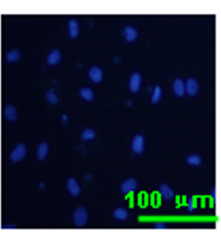

Control

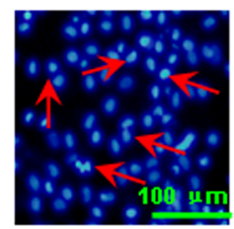

$\mathrm{H} / \mathrm{R}$

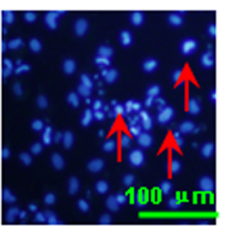

H/R+NaHS

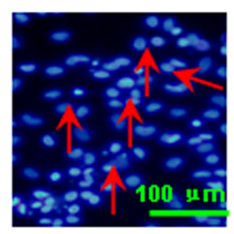

PC

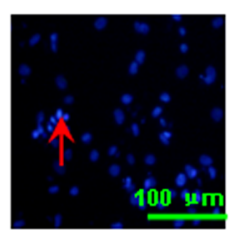

$\mathrm{PC}+\mathrm{NaHS}$

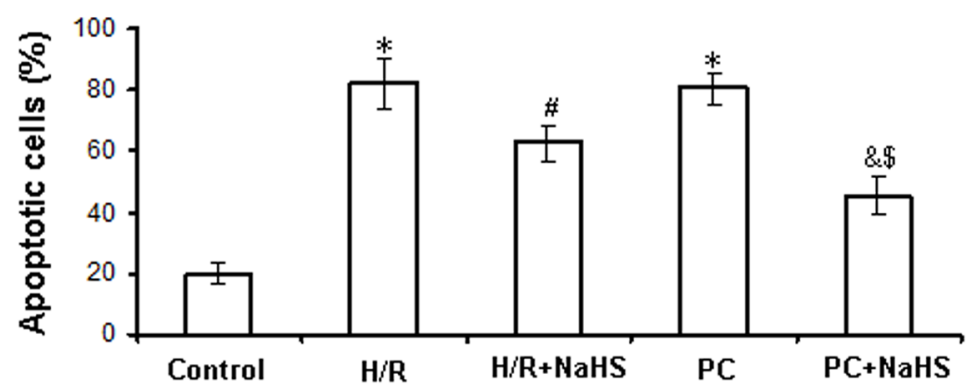

Fig. 4 The effect of exogenous $\mathrm{H}_{2} \mathrm{~S}$ on the cell viability and apoptosis in the $\mathrm{D}$-galactose age-induced primary cultured neonatal cardiomyocytes. a Cell viability was measured by MTT assay. The cells incubated with control medium were considered $100 \%$ viable. b Apoptosis analyzed by flow cytometry. c Detection of nuclear morphology in apoptotic cells by Hoechst 33342 staining. Apoptotic cells were identified as cells with condensed, disrupted nuclei (arrow, Hoechst staining, $\times 400)$. Scale bar $100 \mu \mathrm{m}$. Apoptotic cells in at least five random fields were counted. All data were from four independent experiments. ${ }^{*} p<0.05$ vs. control group; ${ }^{\sharp} p<0.05$ vs. H/R group; ${ }^{\&} p<0.05$ vs. PC group; ${ }^{\$} p<0.05$ vs. H/R + NaHS group. 


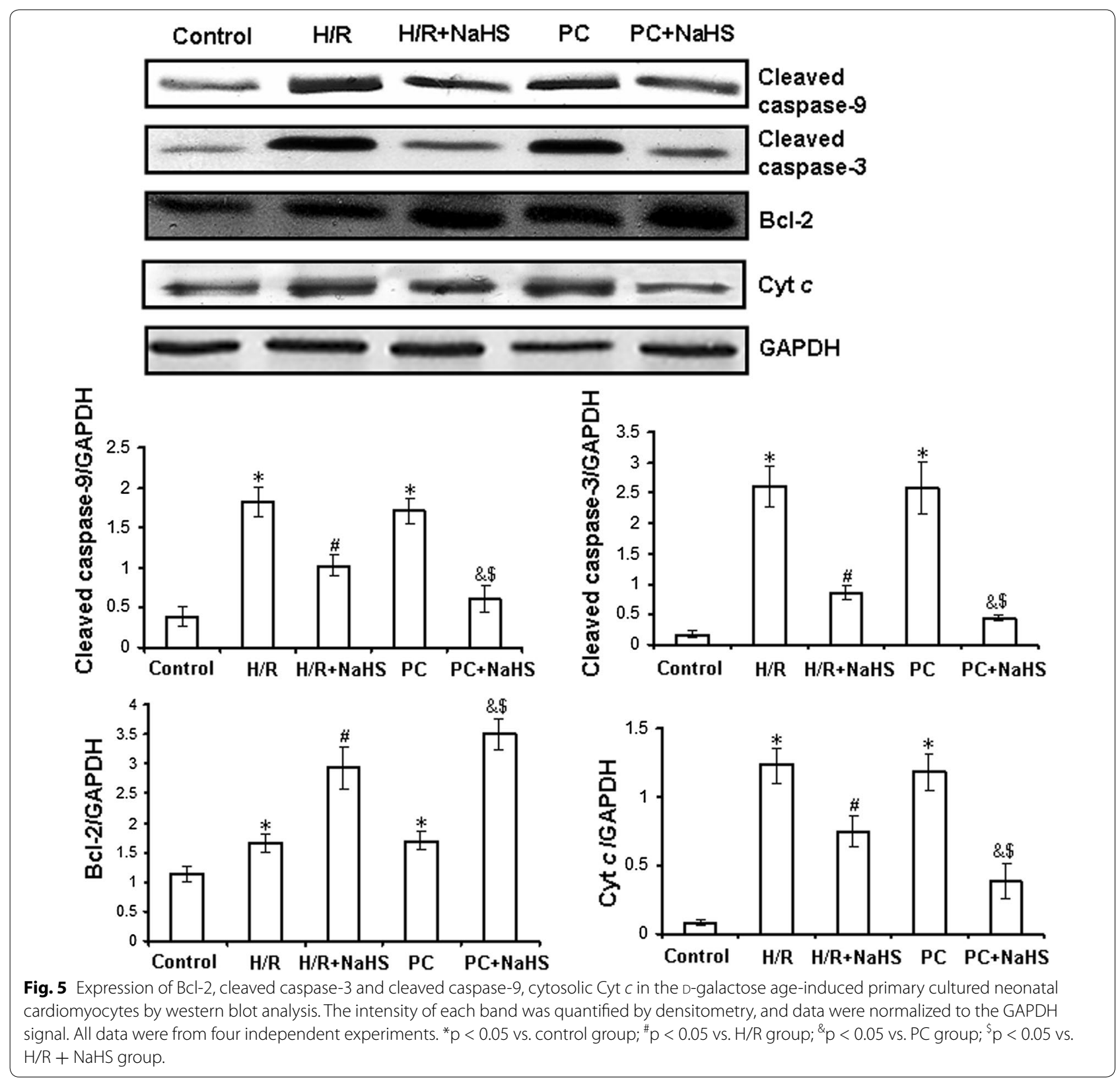

groups but not in the Control, H/R, H/R + Che (a specific inhibitor of $\mathrm{PKC}), \mathrm{H} / \mathrm{R}+\mathrm{Che}+\mathrm{NaHS}, \mathrm{PC}, \mathrm{PC}+$ Che and $\mathrm{PC}+\mathrm{Che}+\mathrm{NaHS}$ groups.

\section{Exogenous $\mathrm{H}_{2} \mathrm{~S}$ increases mitochondrial membrane potential $(\Delta \psi \mathrm{m})$ and inhibits MPTP opening in the D-galactose age-induced primary cultured neonatal cardiomyocytes}

The decreased $\Delta \psi \mathrm{m}$ induces $\mathrm{mPTP}$ opening and then damages celles. To explore the effect of exogenous $\mathrm{H}_{2} \mathrm{~S}$ on the recovery of $\mathrm{PC}$-induced cardioprotection, we observed the changes of $\Delta \psi \mathrm{m}$ and mPTP. As shown in Fig. 9a, the $\Delta \psi \mathrm{m}$ in the $\mathrm{H} / \mathrm{R}$ group was significantly decreased (vs. the control group, $\mathrm{p}=0.0003, \mathrm{p}<0.05)$. The $\Delta \psi \mathrm{m}$ in the $H / R+N a H S$ group was significantly increased (vs. the $H / R$ group, $\mathrm{p}=0.0008, \mathrm{p}<0.05$ ). The $\Delta \psi \mathrm{m}$ of the $\mathrm{PC}$ group was similar to that in the $H / R$ group. The $\Delta \psi \mathrm{m}$ in the $\mathrm{PC}+\mathrm{NaHS}$ group was higher than that of the $\mathrm{H} / \mathrm{R}+\mathrm{NaHS}$ and PC groups $(\mathrm{p}=0.0009, \mathrm{p}<0.05)$. PD98059, LY294002, 5-HD (an inhibitor of $\mathrm{mK}_{\mathrm{ATP}}$ ) and Che reversed the increase of the $\Delta \psi \mathrm{m}$ by NaHS.

At the same time, we assessed mPTP opening with calcein-AM in the different groups. As shown in Fig. 9b, the fluorescence intensity was reduced in the $H / R$ group ( $\mathrm{p}=0.0007, \mathrm{p}<0.05$ vs. control group). H/R + NaHS resulted in increased fluorescence intensity as compared 

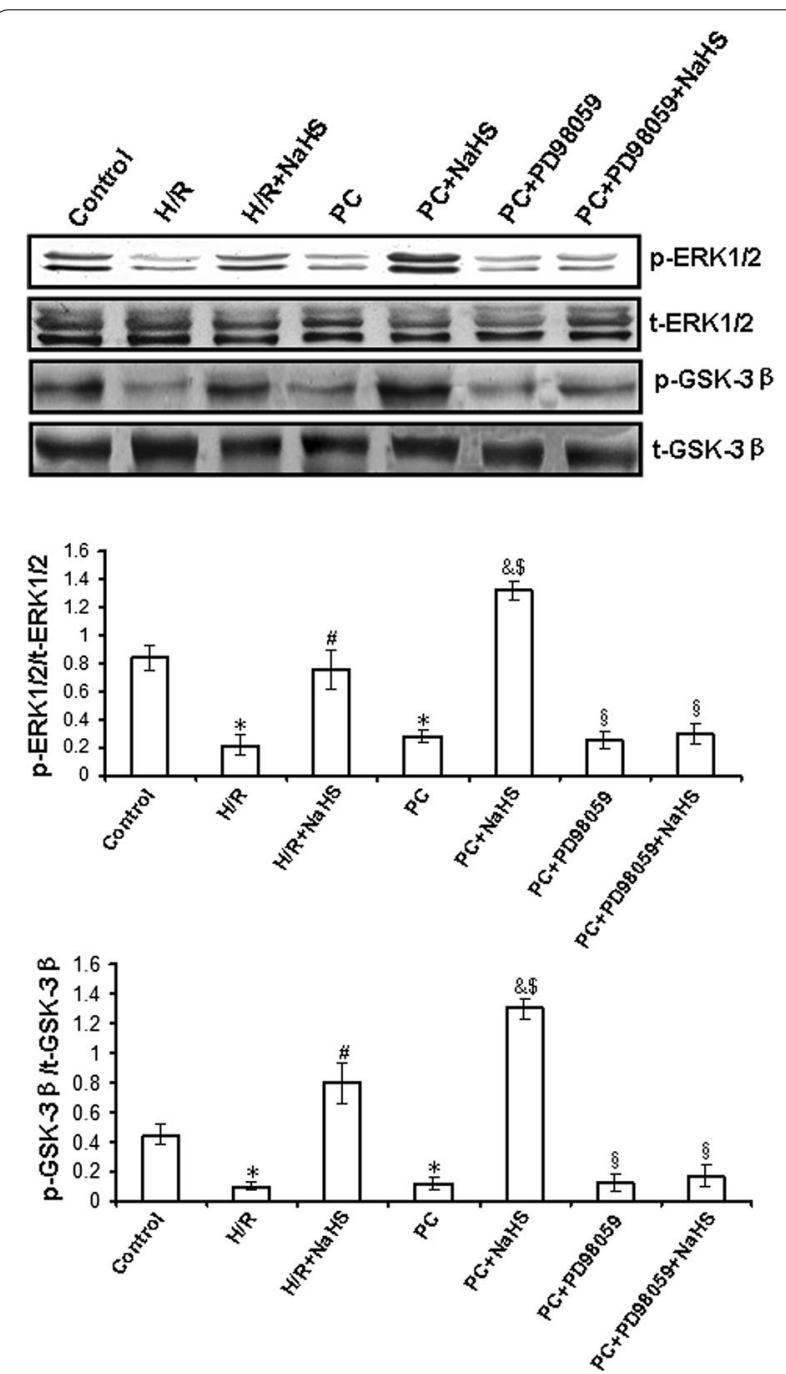

Fig. 6 The change of ERK $1 / 2$ and GSK-3 $\beta$ activities in the $D$-galactose age-induced primary cultured neonatal cardiomyocytes. The different cells were collected and subjected to western blot. The graphs represent the optical density of the band of phosphorylated ERK1/2 and

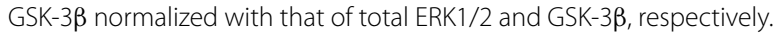
All data were from four independent experiments. ${ }^{*} p<0.05 \mathrm{vs}$. control group; ${ }^{*} \mathrm{p}<0.05$ vs. H/R group; ${ }^{\circledR} p<0.05$ vs. PC group; ${ }^{\$} p<0.05$ vs. $\mathrm{H} / \mathrm{R}+\mathrm{NaHS}$ group; ${ }^{\S} \mathrm{p}<0.05$ vs. $\mathrm{PC}+\mathrm{NaHS}$ group.

to the $H / R$ group $(p=0.0006, p<0.05)$. The fluorescence intensity of the $P C$ group was similar to the $H / R$ group. $\mathrm{PC}+\mathrm{NaHS}$ further increased the fluorescence as compared to the $\mathrm{H} / \mathrm{R}+\mathrm{NaHS}$ and $\mathrm{PC}$ groups $(\mathrm{p}=0.0008, \mathrm{p}<0.05)$, while PD98059, LY294002, 5-HD and Che blocked the increase in fluorescence intensity caused by $\mathrm{PC}+\mathrm{NaHS}$.

\section{Discussion}

The senescent phenotype is associated with a typical gene expression profile and higher SA $\beta$-gal activity [28, 33]. At same time, AGE content is also considered to be one of the most important markers in aging [34]. Cell cycle progression is determined by the formation of protein complexes between cyclins and cyclin-dependent kinases (cdk), and cyclin D associates with cdk2, cdk4, and cdk6 for the determination of early G1 progression [35]. Also involved in the control of cyclin-cdk activity in all phases of the cell cycle is p21 ${ }^{\text {Cip/WAF-1 }}$ [35]. The increase of cyclin D1 and the decrease of $\mathrm{p} 21^{\mathrm{Cip} / \mathrm{WAF}-1}$ reflect cell growth and division. It is well known that the cell division index reflects cell growth, and senescent cells cannot undergo cell division. Our data showed that the number of SA $\beta$-gal-positive cells, the AGE content and the expression of $\mathrm{p} 21^{\mathrm{Cip} / \mathrm{WAF}-1}$ were increased and cyclin D1 expression was decreased in cardiomyocytes, while the H9C2 cell division index was markedly decreased, in treated with $10 \mathrm{~g} / \mathrm{L} \mathrm{D}$-galactose for $48 \mathrm{~h}$ (Table 1; Fig. 1). This indicates the successful establishment of the D-galactose-induced cardiomyocyte aging model used in the present study. As primary cultured neonatal cardiomyocytes cannot divide, the cell division index was assessed using $\mathrm{H} 9 \mathrm{C} 2$ cells (cardiomyocytes line).

$\mathrm{I} / \mathrm{R}$ can induce tissue and organ injury, as well as apoptosis. The mechanisms of apoptosis include the activation of mitochondrial death receptors and/or endoplasmic reticulum stress pathways [9]. The mitochondrial pathway is the major apoptosis-inducing pathway. The intrinsic or mitochondrial pathway transduces a wide spectrum of death signals that originate from both outside and inside the cells. The stimulation of these pathways triggers the translocation of death-promoting proteins (e.g., Cyt c) from the mitochondria to the cytoplasm [36, 37] and the activation of a class of cysteine proteases called caspases, which initiate apoptosis [37]. PC protects cardiac against I/R injury and apoptosis by improving cardiac function, decreasing infarct size and inhibiting apoptosis, among other mechanisms [5, 7, 38]. However, it was recently reported that PC loses its myocardial protective effect in ageing hearts [13-15]. The main reason is that, during ageing, cardiomyocytes undergo complex changes, which finally result in loss of contractile function and loss of endogenous protection against irreversible injury [13-15]. Aging affects cardiomyocytes at several subcellular and molecular levels, including alterations at the level of the DNA, increased oxidative stress, changes in gene/protein expression and posttranslational modifications, and the handling of cellular 'waste' material by autophagy [13-15]. All these alterations decrease the tolerance of cardiomyocytes to stress [13-15]. Our data showed that in the normal primary cultured neonatal cardiomyocytes, compared with $H / R$ group, $P C$ increased cell viability and Bcl-2 mRNA level, decreased the percentage of apoptotic cells and mRNA level of caspase-3 and caspase-9 (Additional file 1: Figures S1, S2). 

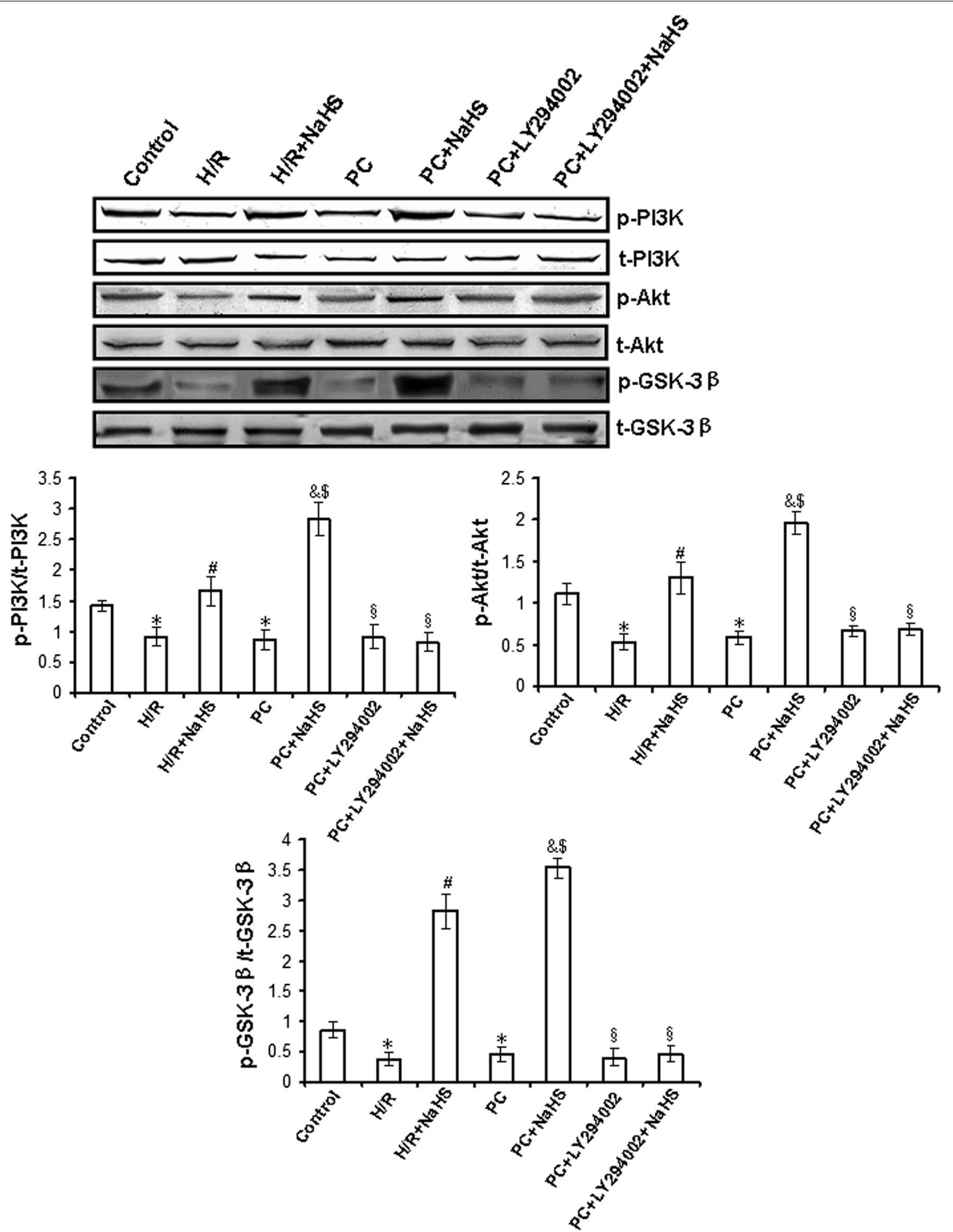

Fig. 7 The change of PI3K, Akt and GSK-3ß activities in the D-galactose age-induced primary cultured neonatal cardiomyocytes. The different cells were collected and subjected to western blot. The graphs represent the optical density of the band of phosphorylated PI3K, Akt and GSK-3ß normal-

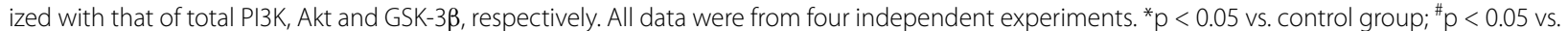
H/R group; ${ }^{\&} p<0.05$ vs. PC group; ${ }^{\$} p<0.05$ vs. H/R + NaHS group; ${ }^{\S} p<0.05$ vs. PC + NaHS group. 


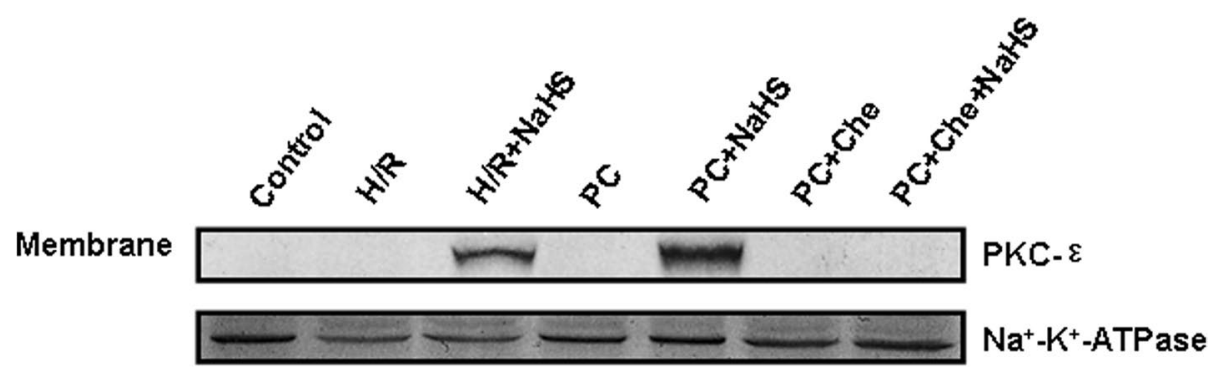

Fig. 8 Translocation of PKC- $\varepsilon$ to cell membrane by Western blot in the D-galactose age-induced primary cultured neonatal cardiomyocytes. Control, $\mathrm{H} / \mathrm{R}, \mathrm{PC}, \mathrm{PC}+\mathrm{Che}$ and PC + Che + NaHS groups showed no translocation of PKC- $\varepsilon$ to cell membrane. H/R + NaHS and PC + NaHS groups showed translocation of PKC- $\varepsilon$ to cell membrane. $\mathrm{Na}^{+} / \mathrm{K}^{+}$-ATPase was used a membrane fraction loading control.
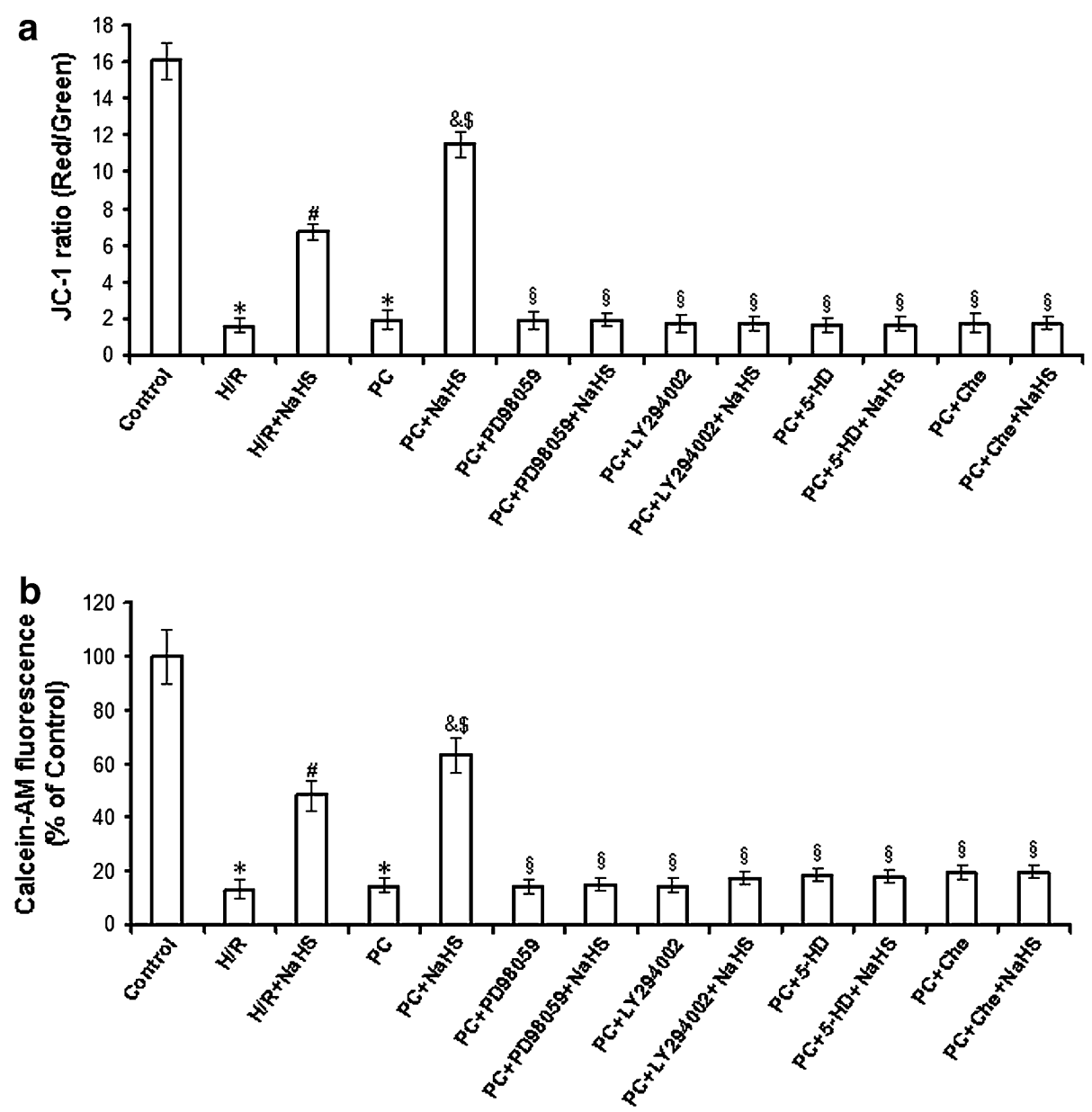

Fig. 9 Analysis of the mitochondrial membrane potential $(\Delta \psi \mathrm{m})$ and mPTP opening in the D-galactose age-induced primary cultured neonatal cardiomyocytes. a JC-1 measured the mitochondrial membrane potential $(\Delta \psi \mathrm{m})$. The cells of different groups were stained with JC-1 probe and imaged by fluorescent microscope. JC-1 spontaneously forms J-aggregate and exhibits red fluorescence under a high potential. The JC-1 monomeric form shows green fluorescence under a low potential. The individual red and green average fluorescence intensities are expressed as the ratio of red to green fluorescence. $\mathbf{b}$ Changes of MPTP opening were measured with calcein-AM. The fluorescence intensity in control group were considered $100 \%$ viable. The changes of fluorescence intensity are inversely proportional with degree of the mPTP opening. All data were from four independent experiments. ${ }^{*} p<0.05$ vs. control group; ${ }^{*} p<0.05$ vs. H/R group; ${ }^{\circledR} p<0.05$ vs. PC group; ${ }^{\$} p<0.05$ vs. H/R $+\mathrm{NaHS}$ group; ${ }^{\S} p<0.05$ vs. $\mathrm{PC}+\mathrm{NaHS}$ group. 
In the D-galactose age-induced cardiomyocytes, the difference in cell viability, the apoptotic rate, and cleaved caspase-9, cleaved caspase-3, Bcl-2 and Cyt $c$ expression between the $\mathrm{H} / \mathrm{R}$ and $\mathrm{PC}$ groups in aging cardiomyocytes was not significant (Figs. 3, 4). These results indicate that PC plays protective role in the normal primary cultured neonatal cardiomyocytes but no in the aging cardiomyocytes.

$\mathrm{H}_{2} \mathrm{~S}$ has long been considered as a pungent cytotoxic gas but now is regarded as the third endogenous signalling gasotransmitter. $\mathrm{H}_{2} \mathrm{~S}$ is generated in mammalian tissues from homocysteine and cysteine in a reaction catalysed by CBS and CSE, the key enzymes of the transulphuration pathway of methionine metabolism [17-19, 37]. CBS is mainly expressed in the brain and peripheral nervous system, whereas CSE is mostly found in vascular and nonvascular smooth muscle cells $[17-19,37]$. Yang and colleagues [24] generated mice lacking CSE (CSE knockout) that had much lower $\mathrm{H}_{2} \mathrm{~S}$ concentrations in the aorta and heart, and their findings suggested that CSE is the major enzyme that maintains $\mathrm{H}_{2} \mathrm{~S}$ concentrations in the cardiovascular system. Recent studies have shown that increased endogenous $\mathrm{CSE} / \mathrm{H}_{2} \mathrm{~S}$ pathway expression or exogenous $\mathrm{H}_{2} \mathrm{~S}$ is involved in PC-induced cardioprotection [39]. Therefore, we proposed that the loss of cardioprotection from $\mathrm{PC}$ in ageing cardiomyocytes is associated with changes in the CSE/ $\mathrm{H}_{2} \mathrm{~S}$ pathway. In the present study, we found that compared with the control group, the $\mathrm{H}_{2} \mathrm{~S}$ production rate of H9C2 cells and CSE expression in ageing cardiomyocytes and $\mathrm{H} 9 \mathrm{C} 2$ cells were significantly decreased in both the $\mathrm{H} / \mathrm{R}$ and $\mathrm{PC}$ groups. The difference in the $\mathrm{H}_{2} \mathrm{~S}$ production rate and CSE expression between the $H / R$ and $P C$ groups was not significant (Fig. 2). We then used NaHS solution as a source of $\mathrm{H}_{2} \mathrm{~S}$ and observed that compared with the $\mathrm{H} / \mathrm{R}$ group, cell viability and $\mathrm{Bcl}-2$ expression were significantly increased, while the apoptotic rate and expression of cleaved caspase- 9 , cleaved caspase- 3 and Cyt $c$ were obviously decreased in the H/R + NaHS group, demonstrating that exogenous $\mathrm{H}_{2} \mathrm{~S}$ reduced H/Rinduced cardiomyocyte injury. This is consistent with previous reports [23, 24]. Meanwhile, we also found that $\mathrm{PC}+\mathrm{NaHS}$ further enhanced the cardioprotective roles of $\mathrm{H} / \mathrm{R}+\mathrm{NaHS}$. These data suggest that exogenous $\mathrm{H}_{2} \mathrm{~S}$ restored $\mathrm{PC}$-induced cardioprotective effects in ageing cardiomyocytes.

To further explore the mechanisms by which exogenous $\mathrm{H}_{2} \mathrm{~S}$ restored PC-induced cardioprotective effects, we assessed changes in mitochondrial membrane potential, mPTP opening and relevant signalling pathways. ERK1/2 is a member of the mammalian mitogen-activated protein kinase family (MAPK), which has a unique role in the regulation of cellular metabolism and gene expression (such

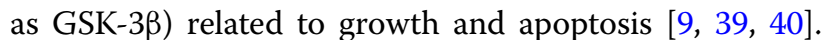
The PI3K-Akt pathway is proximal to endothelial nitric oxide synthase $[9,41,42]$, and its activation also results in the phosphorylation of downstream GSK-3 $\beta$ and, consequently, regulating cell biological and pathological functions. The current study suggests that the up-regulation of the ERK1/2-GSK-3 $\beta$ and PI3-Akt-GSK-3 $\beta$ pathways may contribute to the protective effect of $\mathrm{PC}$ through the inhibition of $\mathrm{mPTP}$ opening [43, 44]. In addition, PKC- $\varepsilon$ activates mitoK ${ }_{\text {ATP }}$ and inhibits MPTP opening, which is involved in cardioprotection during PC [45]. We showed here that $\mathrm{H} / \mathrm{R}+\mathrm{NaHS}$ promoted the phosphorylation of the ERK1/2-GSK-3 $\beta$ and PI3K-Akt-GSK-3 $\beta$ pathways and the translocation of PKC- $\varepsilon$ to the cell membrane, increased the mitochondrial membrane potential and inhibited mPTP opening (Figs. 5, 6, 7, 8; Additional file 1: Figures S3, S4, S5). PC + NaHS further enhanced the effects of $\mathrm{H} / \mathrm{R}+\mathrm{NaHS}$. PD98059 (an inhibitor of ERK1/2 signalling), LY 294002 (a PI3K inhibitor), Che (a PKC inhibitor) and 5-HD (a mitoK ${ }_{\text {ATP }}$ inhibitor) abolished the effects of PC $+\mathrm{NaHS}$, respectively (Figs. 5, 6, 7, 8; Additional file 1: Figures S3, S4, S5). Taken together,

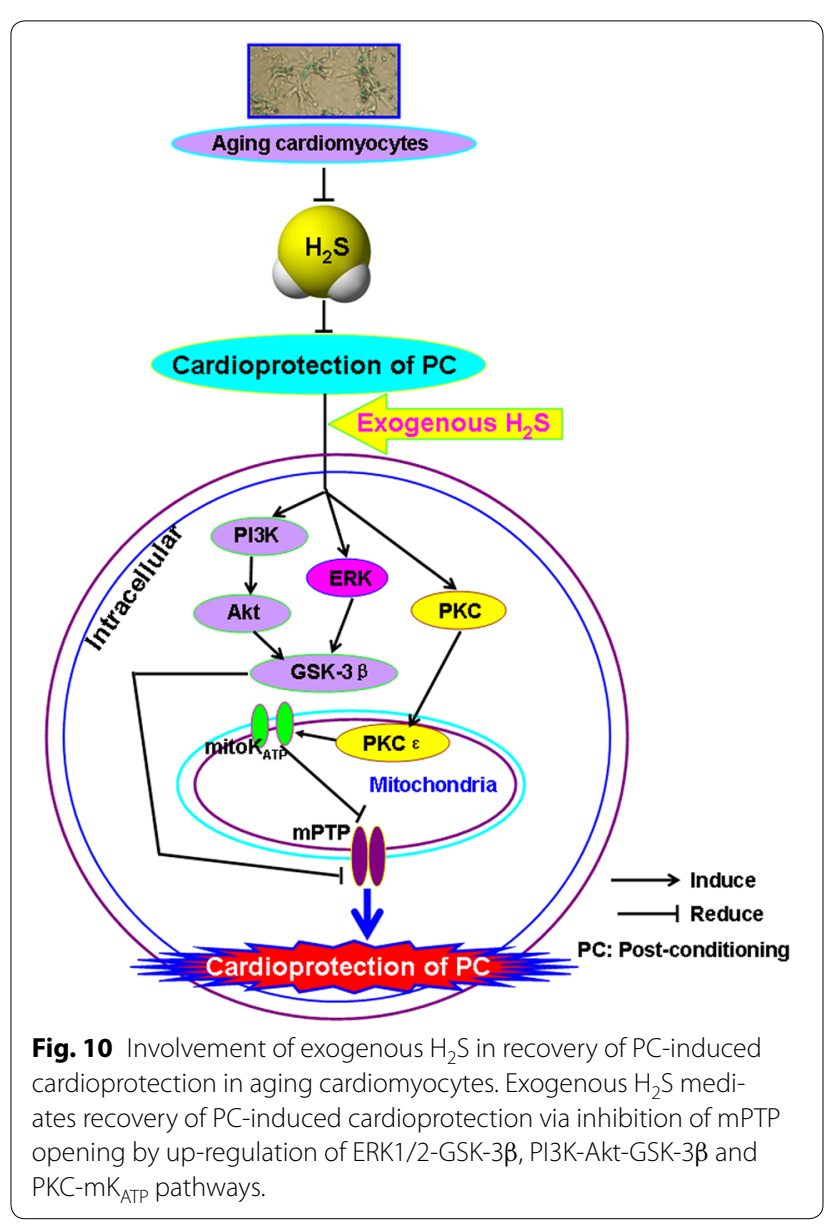


these findings suggest that exogenous $\mathrm{H}_{2} \mathrm{~S}$ plays an important role in the recovery of PC-induced cardioprotection by inhibiting $\mathrm{MPTP}$ opening through the phosphorylation

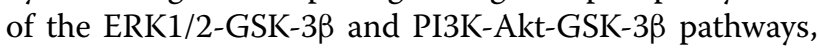
as well as the activation of the PKC- $\varepsilon$-mitoK ${ }_{\text {ATP }}$ pathway.

In summary (Fig. 10), the present research demonstrated that (1) H/R causes injury to aging cardiomyocytes and that exogenous $\mathrm{H}_{2} \mathrm{~S}$ reduces $\mathrm{H} / \mathrm{R}$ injury. (2) In aging cardiomyocytes, $\mathrm{PC}$ loses its cardioprotective effects on $H / R$ injury and exogenous $\mathrm{H}_{2} \mathrm{~S}$ recovers PC-induced cardioprotection by inhibiting $\mathrm{MPTP}$ opening via the activation of the ERK1/2-GSK-3 $\beta$, PI3KAkt-GSK-3 $\beta$ and PKC- $\varepsilon-\mathrm{mK}_{\text {ATP }}$ pathways. Dissection of the mechanisms underlying $\mathrm{H}_{2} \mathrm{~S}$ protection should facilitate novel preventive and therapeutic approaches for ischemic cardiomyopathy in the aging process.

\section{Additional file}

Additional file 1: Figure S1. The change of the cell viability and apoptosis in the normal primary cultured neonatal cardiomyocytes. Figure S2. The change of caspase- 3 , caspase- 9 and $\mathrm{BCl}-2$ mRNA levels in the normal primary cultured neonatal cardiomyocytes. Figure S3. The effect of exogenous $\mathrm{H}_{2} \mathrm{~S}$ on $\mathrm{p}$-ERK1/2 and $\mathrm{p}$-GSK-3 $\beta$ mRNA levels in the D-galactose age-induced cardiomyocytes. Figure S4. The effect of exogenous $\mathrm{H}_{2} \mathrm{~S}$ on $\mathrm{p}-\mathrm{PI} 3 \mathrm{~K}$, $\mathrm{p}$-Akt and $\mathrm{p}-\mathrm{GSK}-3 \mathrm{~B}$ mRNA levels in the D-galactose age-induced cardiomyocytes. Figure S5. The effect of exogenous $\mathrm{H}_{2} \mathrm{~S}$ on PKC $-\varepsilon$ mRNA levels in the cell membrane in the $\mathrm{D}$-galactose age-induced cardiomyocytes

\section{Authors' contributions}

$H L$ and $C X$ conceived and designed the research, and drafted the manuscript, $C Z, W S, L L$ and SB performed the experiments. $H L, B W, X Z, R W$ and $L W$ revised the paper and gave some suggestions. All authors read and approved the final manuscript.

\section{Author details \\ ${ }^{1}$ Department of Pathophysiology, Harbin Medical University, Baojian Road, Harbin 150081, China. ${ }^{2}$ Department of Emergency, Heilongjiang Provin- cial Hospital, Harbin 150036, China. ${ }^{3}$ The Key Laboratory of Cardiovascular Medicine Research (Harbin Medical University), Ministry of Education, Har- bin 150086, China. ${ }^{4}$ Department of Biology, Lakehead University, Thunder Bay, ON P7B 5E1, Canada. ${ }^{5}$ Department of Health Science, Lakehead University, Thunder Bay, ON P7B 5E1, Canada.}

\section{Acknowledgements}

This research is supported by the National Natural Science Foundation of China (No. 81270273, No. 81000059, No. 81270311, No. 81400210), the Natural Science Foundation of Heilongjiang (No. LC201430).

\section{Compliance with ethical guidelines}

\section{Competing interests}

The authors declare that they have no competing interests.

Received: 16 April 2015 Accepted: 20 July 2015

Published online: 30 July 2015

\section{References}

1. Murry CE, Jennings RB, Reimer KA. Preconditioning with ischemia: a delay of lethal cell injury in ischemic myocardium. Circulation. 1986;74:1124-36.
2. Mockford KA, Girn HR, Homer-Vanniasinkam S. Postconditioning: current controversies and clinical implications. Eur J Vasc Endovasc Surg. 2009;37:437-42.

3. Chen YH, Wu XD, Yao ST, Sun S, Liu XH. Calcineurin is involved in cardioprotection induced by ischemic postconditioning through attenuating endoplasmic reticulum stress. Chin Med J (Engl). 2011;124:3334-40.

4. Zhao ZQ, Corvera JS, Halkos ME, Kerendi F, Wang NP, Guyton RA, et al. Inhibition of myocardial injury by ischemic postconditioning during reperfusion: comparison with ischemic preconditioning. Am J Physiol Heart Circ Physiol. 2003;285:H579-88.

5. Yong QC, Lee SW, Foo CS, Neo KL, Chen X, Bian JS. Endogenous hydrogen sulphide mediates the cardioprotection induced by ischemic postconditioning. Am J Physiol Heart Circ Physiol. 2008;295:H1330-40.

6. Tsang A, Hausenloy DJ, Mocanu MM, Yellon DM. Postconditioning: a form of "modified reperfusion" protects the myocardium by activating the phosphatidylinositol 3-kinase-Akt pathway. Circ Res. 2004;95:230-2.

7. Zhu M, Feng J, Lucchinetti E, Fischer G, Xu L, Pedrazzini T, et al. Ischemic postconditioning protects remodeled myocardium via the PI3KPKB/Akt reperfusion injury salvage kinase pathway. Cardiovasc Res. 2006;72:152-62.

8. Darling CE, Jiang R, Maynard M, Whittaker P, Vinten-Johansen J, Przyklenk K. Postconditioning via stuttering reperfusion limits myocardial infarct size in rabbit hearts: role of ERK1/2. Am J Physiol Heart Circ Physiol. 2005;289:H1618-26.

9. Li H, Wei C, Gao J, Bai S, Li H, Zhao Y, et al. Mediation of dopamine D2 receptors activation in post-conditioning-attenuated cardiomyocyte apoptosis. Exp Cell Res. 2014;323:118-30.

10. Philipp S, Yang XM, Cui L, Davis AM, Downey JM, Cohen MV. Postconditioning protects rabbit hearts through a protein kinase $\mathrm{C}$-adenosine $\mathrm{A} 2 \mathrm{~b}$ receptor cascade. Cardiovasc Res. 2006;70:308-14.

11. Zatta AJ, Kin H, Lee G, Wang N, Jiang R, Lust $R$, et al. Infarctsparing effect of myocardial postconditioning is dependent on protein kinase $\mathrm{C}$ signalling. Cardiovasc Res. 2006;70:315-24.

12. Hausenloy DJ, Tsang A, Yellon DM. The reperfusion injury salvage kinase pathway: a common target for both ischemic preconditioning and postconditioning. Trends Cardiovasc Med. 2005;15:69-75.

13. Boengler K, Schulz R, Heusch G. Loss of cardioprotection with ageing. Cardiovasc Res. 2009:83:247-61.

14. Jahangir A, Sagar S, Terzic A. Aging and cardioprotection. Appl Physiol. 2007:103:2120-8

15. Chen Q, Ross T, Hu Y, Lesnefsky EJ. Blockade of electron transport at the onset of reperfusion decreases cardiac injury in aged hearts by protecting the inner mitochondrial membrane. J Aging Res. 2012;2012:753949.

16. Zhao K, Li H, Li S, Yang G. Regulation of cystathionine gamma-lyase/ $\mathrm{H} 2 \mathrm{~S}$ system and its pathological implication. Front Biosci (Landmark Ed). 2014;19:1355-69.

17. Yang GD, Li HZ, Tang GH, Wu LY, Zhao KX, Cao QH, et al. Increased neointimal formation in cystathionine gamma-lyase deficient mice: role of hydrogen sulfide in $\alpha 5 \beta 1$-integrin and matrix metalloproteinase-2 expression in smooth muscle cells. J Mol Cell Cardiol. 2012:52:677-88.

18. Yang GD. Hydrogen sulfide in cell survival: a double-edged sword. Expert Rev Clin Pharmacol. 2011:4:33-47.

19. Meng QH, Yang G, Yang W, Jiang B, Wu L, Wang R. Protective effect of hydrogen sulfide on balloon injury-induced neointima hyperplasia in rat carotid arteries. Am J Pathol. 2007;170:1406-14.

20. Dayal S, Bottiglieri T, Arning E, Maeda N, Malinow MR, Sigmund CD, et al. Endothelial dysfunction and elevation of S-adenosylhomocysteine in cystathionine beta-synthase-deficient mice. Circ Res. 2001;88:1203-9.

21. Mani S, Li H, Untereiner A, Wu L, Yang G, Austin RC, et al. Decreased endogenous production of hydrogen sulfide accelerates atherosclerosis. Circulation. 2013:127:2523-34.

22. Wang R. Two's company, three's a crowd: $\mathrm{can}_{2} \mathrm{H}_{2} \mathrm{~S}$ be the third endogenous gaseous transmitter? Faseb J. 2002;16:1792-8.

23. Wang R. The gasotransmitter role of hydrogen sulfide. Antioxid Redox Sig. 2003;5:493-501.

24. Yang $\mathrm{G}, \mathrm{Wu} \mathrm{L}$, Jiang $\mathrm{B}$, Yang $\mathrm{W}, \mathrm{Qi}$ J, Cao $\mathrm{K}$, et al. $\mathrm{H}_{2} \mathrm{~S}$ as a physiologic vasorelaxant: hypertension in mice with deletion of cystathionine gammalyase. Science. 2008;322:587-90. 
25. Li HZ, Mani S, Cao W, Yang GD, Lai C, Wu LY, et al. Interaction of hydrogen sulfide and estrogen on the proliferation of vascular smooth muscle cells. PLoS One. 2012;7:e41614.

26. Zhao W, Zhang J, Lu Y, Wang R. The vasorelaxant effect of $\mathrm{H}_{2} \mathrm{~S}$ as a novel endogenous gaseous $K_{\text {ATP }}$ channel opener. EMBO J. 2001;20:6008-16.

27. Li HZ, Wang YH, Wei C, Bai SZ, Zhao YJ, Li HX, et al. Mediation of exogenous hydrogen sulfide in recovery of ischemic post-conditioninginduced cardioprotection via down-regulating oxidative stress and up-regulating PI3K/Akt/GSK-3 $\beta$ pathway in isolated aging rat hearts. Cel Biosci. 2015;5:11.

28. Li HZ, Guo J, Gao J, Han LP, Jiang CM, Li HX, et al. Role of dopamine D2 receptors in ischemia/reperfusion induced apoptosis of cultured neonatal rat cardiomyocytes. J Biomed Sci. 2011;18:18.

29. Liu J, Wang J, Chen X, Guo C, Guo Y, Wang H. Ginkgo biloba extract EGB761 protects against aging-associated diastolic dysfunction in cardiomyocytes of D-galactose-induced aging rat. Oxid Med Cell Longev. 2012;2012:418748.

30. Chen B, Zhong Y, Peng W, Sun Y, Kong WJ. Agerelated changes in the central auditory system: comparison of D-galactose-induced aging rats and naturally aging rats. Brain Res. 2010;1344:43-53.

31. Li HZ, Han LP, Jiang CM, Li H, Zhao YJ, Gao J, et al. Effect of dopamine receptor 1 on apoptosis of cultured neonatal rat cardiomyocytes in simulated ischaemia/reperfusion. Basic Clin Pharmacol Toxicol. 2008;102:329-36.

32. Hausenloy D, Wynne A, Duchen M, Yellon D. Transient mitochondrial permeability transition pore opening mediates preconditioning-induced protection. Circulation. 2004;109:1714-7.

33. Dimri GP, Lee X, Basile G, Acosta M, Scott G, Roskelley C, et al. A biomarker that identifies senescent human cells in culture and in aging skin in vivo. Proc Natl Acad Sci USA. 1995;92:9363-7.

34. Li SY, Du M, Dolence EK, Fang CX, Mayer GE, Ceylan-Isik AF, et al. Aging induces cardiac diastolic dysfunction, oxidative stress, accumulation of advanced glycation endproducts and proteinmodification. Aging Cell. 2005;2:57-64

35. Yang G, Wu L, Bryan S, Khaper N, Mani S, Wang R. Cystathionine gammalyase deficiency and overproliferation of smooth muscle cells. Cardiovasc Res. 2010;86:487-95.
36. Narula J, Pandey P, Arbustini E, Haider N, Narula N, Kolodgie FD. Apoptosis in heart failure: release of cytochrome $\mathrm{c}$ from mitochondria and activation of caspase-3 in human cardiomyopathy. Proc Natl Acad Sci. 1999;96:8144-9.

37. Zhong X, Wang L, Wang Y, Dong S, Leng X, Jia J, et al. Exogenous hydrogen sulfide attenuates diabetic myocardial injury through cardiac mitochondrial protection. Mol Cell Biochem. 2012;371:187-98.

38. Wang HC, Zhang HF, Guo WY, Su H, Zhang KR, Li QX, et al. Hypoxic postconditioning enhances the survival and inhibits apoptosis of cardiomyocytes following reoxygenation: role of peroxynitrite formation. Apoptosis. 2006:11:1453-60.

39. Ji Y, Pang QF, Xu G, Wang L, Wang JK, Zeng YM. Exogenous hydrogen sulfide postconditioning protects isolated rat hearts against ischemiareperfusion injury. Eur J Pharmacol. 2008;587:1-7.

40. Xia Z, Dickens M, Raingeaud J, Davis RJ, Greenberg ME. Opposing effects of ERK and JNK-p38 MAP kinases on apoptosis. Science. 1995;270:1326-31.

41. Hausenloy DJ, Yellon DM. Survival kinases in ischemic preconditioning and postconditioning. Cardiovasc Res. 2006;70:240-53.

42. Vinten-Johansen J. Postconditioning: a mechanical maneuver that triggers biological and molecular cardioprotective responses to reperfusion. Heart Fail Rev. 2007;12:235-44.

43. Gao X, Zhang H, Takahashi T, Hsieh J, Liao J, Steinberg GK, et al. The Akt signaling pathway contributes to postconditioning's protection against stroke; the protection is associated with the MAPK and PKC pathways. J Neurochem. 2008;105:943-55

44. Pignataro G, Meller R, Inoue K, Ordonez AN, Ashley MD, Xiong Z, et al. In vivo and in vitro characterization of a novel neuroprotective strategy for stroke: ischemic postconditioning. J Cereb Blood Flow Metab. 2008;28:232-41.

45. Hausenloy DJ, Ong SB, Yellon DM. The mitochondrial permeability transition pore as a target for preconditioning and postconditioning. Basic Res Cardiol. 2009;104:189-202.

\section{Submit your next manuscript to BioMed Central and take full advantage of:}

- Convenient online submission

- Thorough peer review

- No space constraints or color figure charges

- Immediate publication on acceptance

- Inclusion in PubMed, CAS, Scopus and Google Scholar

- Research which is freely available for redistribution

Submit your manuscript at 